\title{
Quasi-tropical cyclone caused anomalous autumn coccolithophore bloom in the Black Sea
}

\author{
Sergey V. Stanichny, Elena A. Kubryakova, and Arseny A. Kubryakov \\ Marine Hydrophysical Institute, Russian Academy of Sciences, Sevastopol, Russian Federation \\ Correspondence: Elena A. Kubryakova (elena_kubryakova@mail.ru)
}

Received: 9 May 2020 - Discussion started: 18 May 2020

Revised: 30 March 2021 - Accepted: 8 April 2021 - Published: 26 May 2021

\begin{abstract}
A quasi-tropical cyclone (QTC) observed over the Black Sea on 25-29 September 2005 caused an exceptionally strong anomalous autumn coccolithophore bloom that lasted for more than 1.5 months. The QTC induced intense upwelling, causing a decrease in sea surface temperature of $15^{\circ} \mathrm{C}$ and an acceleration of the cyclonic Rim Current up to extreme values of $0.75 \mathrm{~m} \mathrm{~s}^{-1}$. The Rim Current transported nutrient-rich Danube plume waters from the northwestern shelf to the zone of the cyclone action. Baroclinic instabilities of the plume boundary caused intense submesoscale processes, accompanied by mixing of the shelf and upwelling of the waters. These processes triggered the initial growth of remote sensing reflectance $\left(R_{\mathrm{rs}}\right)$ on the offshore front of the plume, indicating the beginning of the coccolithophore bloom. Furthermore, the bloom shifted to the zone of the strongest upwelling in the western cyclonic gyre. Intense vertical entrainment of nutrients in this area caused the increase in chlorophyll $a$ concentration (Chl), which was then followed by a strong bloom of coccolithophores. Advection by the Rim Current spread the bloom over the entire southern part of the Black Sea, more than $1000 \mathrm{~km}$ from its initial source. A month after the QTC action, $R_{\mathrm{rs}}$ in these areas reached a value of $0.018 \mathrm{sr}^{-1}$, corresponding to an estimate of a coccolithophore concentration of $10^{7}$ cells per liter.
\end{abstract}

\section{Introduction}

Vertical mixing and upwelling caused by the action of tropical cyclones uplift nutrients to the euphotic layer and induce intense, sporadic phytoplankton blooms in the world ocean (for example, Babin et al., 2004; Chacko, 2017; Han et al., 2012; Kubryakov et al., 2019c; Lin et al., 2003; Miller et al.,
2006; Morozov et al., 2015; Tsuchiya et al., 2013). An important tracer of such changes is the chlorophyll $a$ concentration (Chl), which can be determined from satellite measurements. Intense nutrient entrainment leads to the rapid rise in $\mathrm{Chl}$, which can be observed several months after the action of the storm in various ocean areas (for example, Shi et al., 2007; Wu et al., 2008), including the Black Sea (Kubryakov et al., 2019c). In some cases, the action of atmospheric cyclones causes the growth of specific groups of phytoplankton. For example, Zhu et al. (2014) showed that the storm action in Lake Taihu led to the intensive growth of potentially toxic cyanobacteria.

At the same time, there is almost no information on the impact of atmospheric cyclones on the development of coccolithophores. Coccolithophores are one of the dominant phytoplankton groups in the ocean. Their specific feature is the ability to form calcified plates - coccoliths - which play a significant role in the ocean carbon pump (Balch et al., 2011; Rigual Hernández et al., 2018, 2020; Krumhardt et al., 2017; Rost and Riebesell, 2004) and the formation of calcareous sediment layers (Coolen, 2011; Hay et al., 1990; Honjo, 1976). Coccolithophores cause significant light scattering and increase the reflectance of the water, which makes it possible to study them using satellite data (Balch et al., 1996; Cokacar et al., 2001, 2004; Holligan et al., 1983; Hopkins et al., 2015; Krumhardt et al., 2017; Moore et al., 2012; Shutler et al., 2013).

Of the strongest coccolithophore blooms in the world ocean, one is observed in the Black Sea (Tyrell and Merico, 2004 ) in the early summer period (May-June; Cokacar et al., 2001, 2004; Mikaelyan et al., 2005, 2011, 2015; Kopelevich et al., 2014). Coccoliths protect cells from photoinhibition, giving them an advantage that enables them to 
grow in summer during high insolation and at a low mixed layer depth (Tyrell and Merico, 2004). Usually, the cell concentration $(N)$ during summer blooms in the Black Sea is $\sim 2-6 \times 10^{6}$ cells per liter (Mikaelyan et al., 2005, 2011, 2015; Pautova et al., 2007), but in certain years, it can reach very high values, where $N=10-30 \times 10^{6}$ cells per liter (Korchemkina et al., 2014; Mihnea, 1997; Yasakova and Stanichny, 2012). Weaker blooms are detected in the winter period (Hay et al., 1990; Kubryakov et al., 2019c, 2021; Mikaelyan et al., 2020; Sorokin, 1983; Stelmakh et al., 2009; Stelmakh, 2013; Sukhanova, 1995; Türkoğlu, 2010; Yasakova et al., 2017). Recent biogeochemical Argo (BGC-ARGO; Kubryakov et al., 2019c) and satellite studies (Kubryakova et al., 2021) showed that winter blooms usually start in December, with a peak in January, and are observed almost every year. $N$ is usually lower in winter than in summer $\left(N=0.5-2 \times 10^{6}\right.$ cells per liter; Kubryakov et al., 2019c; Stelmakh et al., 2009; Stelmakh, 2013).

In autumn 2005, satellite data detected a very strong bloom of coccolithophores, anomalous both by its intensity and timing. This bloom was observed after an action of a very intense quasi-tropical cyclone (QTC) observed over the Black Sea in September 2005 (Efimov et al., 2008; Yarovaya et al., 2008). Tropical cyclones (or typhoons) are usually originated at latitudes less than $30^{\circ}$ (see the review in Emanuel, 2003). However, an anomalous atmospheric cyclone that formed over the Black Sea basin at $40^{\circ}$ E on 25-29 September (Fig. 1a) had all the characteristic features of the tropical cyclones. It had spiral cloud bands, a warm core, a pronounced eye of the cyclone, and high wind velocity reaching $25 \mathrm{~m} \mathrm{~s}^{-1}$ (Efimov et al., 2007, 2008). Similar cyclones were documented (albeit rarely) in the Mediterranean Sea (Pytharoulis et al., 1995; Homar et al., 2003) but never before over the Black Sea. Later, a detailed statistical study of the characteristics of the atmospheric cyclones over the Black Sea (Efimov et al., 2009) showed that cyclones with such large intensity were detected over the Black Sea only three times during a 30year period. A unique characteristic of the QTC in September 2005 was its quasi-stationarity. It acted on the Black Sea for more than $4 \mathrm{~d}$, which led to significant changes in the Black Sea dynamics and ecosystem.

This paper documents, for the first time, the impact of such an anomalous quasi-tropical atmospheric cyclone on the development and evolution of autumn coccolithophore bloom in the Black Sea on the basis of satellite optical, infrared, and altimetric data.

\section{Data and methods}

For the analysis of the coccolithophore bloom in the Black Sea, level 2 MODIS (Moderate Resolution Imaging Spectroradiometer) Aqua daily maps of remote sensing reflectance at a wavelength of $555 \mathrm{~nm}\left(R_{\mathrm{rs}}\right)$ and Chl for SeptemberNovember 2005, with a spatial resolution of $1 \mathrm{~km}$ and a time of $1 \mathrm{~d}$, were used. High $R_{\mathrm{rs}}$ values are caused by increased backscattering on particles. In the deep part of the Black Sea, the rapid growth of $R_{\mathrm{rs}}$ is mainly caused by scattering on coccoliths during the coccolithophore bloom (Cokacar et al., 2001, 2004; Kopelevich et al., 2014). Another strong source of backscattering and the reflectance increase in the enclosed Black Sea is lithogenic particles originating from river discharge due to coastal erosion from the resuspension of bottom sediments. These processes mainly occur in the shelf area of the basin (see more details in Sect. 3.3).

In the areas of coccolithophore bloom, their cell concentration ( $N$, cells per liter) can be estimated on the basis of backscattering or $R_{\mathrm{rs}}$ data (see Gordon and Balch, 1999). In this paper, we use the following equation:

$N=0.8 \times 10^{9} \times b_{\text {bp }}(700)^{1.21}$,

and the linear relationship between $R_{\mathrm{rs}}(555)$ and backscattering coefficient $\left(b_{\mathrm{bp}}, \mathrm{m}^{-1}\right) b_{\mathrm{bp}}(700)-R_{\mathrm{rs}}=0.7 \times b_{\mathrm{bp}}(700)-$ to give an estimate of the coccolithophores concentration on the basis of satellite data. It should be noted that this formula is very approximate and gives only rough estimates of $N$. The backscattering during coccolithophore bloom represents a mixture of the signals from the plated coccolithophores and detached coccoliths. The number of coccoliths per cell can vary strongly. In this paper, we use an average value of 30 coccoliths per cell. However, this value can change from 10 (Balch et al., 1991) to more than 50 (Mikaelyan et al., 2005). In the coastal areas, $R_{\mathrm{rs}}$ represents the mixture of signals from riverine particles and coccoliths (Kopelevich et al., 2014). These signals can be separated using a twoparametric model (Kopelevich et al., 2014), which is based on the data on the absorption coefficient of yellow substance $\left(a_{g}\right)$ and $R_{\mathrm{rs}}$. In our study, we used a more simple approach (Eq. 1) to give only approximate estimates of the maximum observed $N$ and the area of a bloom. The phytoplankton bloom is usually subjectively defined as the conditions when $N$ exceeds $10^{6}$ cells per liter. According to Eq. (1), it corresponds to the value of $R_{\mathrm{rS}}=0.005 \mathrm{sr}^{-1}$. The area of the coccolithophore bloom was estimated as a total area, with values of $R_{\mathrm{rs}} \geq 0.005 \mathrm{sr}^{-1}$. To exclude the impact of lithogenic particles on the shelf, we used only pixels located in the deep part of the basin (depths of more than $500 \mathrm{~m}$ ).

We used the daily level 2B array of QuikSCAT wind data provided on a nonuniform grid within the swath at $12.5 \mathrm{~km}$ pixel resolution for September-November 2005. Data were downloaded from https://podaac.jpl.nasa.gov/ dataset/QSCAT_LEVEL_2B_OWV_COMP_12 (last access: 11 May 2021). The Ekman pumping was defined as $\overrightarrow{W_{\mathrm{ek}}}=$ $\frac{1}{\rho_{\mathrm{w}} \cdot f} \operatorname{rot}(\boldsymbol{\tau})$, where $\rho_{\mathrm{w}}=1000 \mathrm{~kg} \mathrm{~m}^{-3}$ is the water density, $\boldsymbol{\tau}=c_{\mathrm{d}} \rho_{\mathrm{a}} \cdot|v| \cdot v$ is the wind stress, $c_{\mathrm{d}}=1.3 \times 10^{-3}$ is the drag coefficient, $\rho_{\mathrm{a}}=1.3 \mathrm{~kg} \mathrm{~m}^{-3}$ is the air density, and $v$ is the wind velocity.

A regional data set on altimetry-derived daily mapped sea level anomalies with $1 / 8^{\circ}$ resolu- 
tion produced by Aviso+. The satellite altimeter data (product identifier: SEALEVEL_BS_PHY_L4_ REP_OBSERVATIONS_008_042) is made freely available by the Copernicus Marine Environmental Monitoring Service (https://resources.marine.copernicus.eu/?option= com_csw\&view=details\&product_id=SEALEVEL_BS PHY_L4_REP_OBSERVATIONS_008_042, last access: 11 May 2021). Mapped sea level anomalies were added to the mean dynamic topography (Kubryakov and Stanichny, 2011) to compute surface geostrophic velocities in the sea. The obtained data set was validated by Kubryakov et al. (2016) with drifters and hydrological data. The analysis of the sea surface temperature (SST) was carried out using measurements of AVHRR (Advanced Very High-Resolution Radiometer) radiometers with a spatial resolution of $1 \mathrm{~km}$.

\section{Results and discussion}

\subsection{Impact of a quasi-tropical cyclone on physical processes in the Black Sea}

From 25-29 September 2005, an anomalous intense QTC was observed in the atmosphere over the Black Sea on satellite imagery (Fig. 1a). It had a cloud-free eye and distinct spiral cloud bands and was no more than $300 \mathrm{~km}$ in diameter. Wind velocity in the cyclone reaches $20-25 \mathrm{~m} \mathrm{~s}^{-1}$, according to the QuikSCAT satellite data (Fig. 1c). Its development occurred after weak wind conditions and was associated with the overheating of the sea surface, which caused increased moisture fluxes over the western part of the Black Sea. Importantly, QTC was observed over the western part of the Black Sea for more than $4 \mathrm{~d}$. A detailed analysis of the dynamics of QTC, and the reasons for its formation, was carried out in Efimov et al. (2007) and Yarovaya et al. (2008).

Cyclonic wind vorticity led to Ekman transport directed from the QTC and Ekman pumping. Particularly, Ekman pumping on 26 September in the zone of QTC action exceeded $4 \times 10^{-5} \mathrm{~m} \mathrm{~s}^{-1}$ (Fig. 1d). Efimov et al. (2008) documented the absolute maximum as reaching $20 \times 10^{-5} \mathrm{~m} \mathrm{~s}^{-1}$. QTC was situated over the western cyclonic gyre of the Black Sea circulation. The center of the western cyclonic gyre was observed in altimetry maps as being an area of a decreased sea level reflecting the uplift of isopycnals (Fig. 2a). On average, in the Black Sea, the pycnocline and nutricline in the centers of the western cyclonic gyre are elevated by $20-30 \mathrm{~m}$ relative to the periphery of the sea (Ivanov and Belokopytov, 2013). Ekman pumping caused additional intense upwelling in this area, which was accompanied by strong wind mechanical mixing. As a result, according to the AVHRR radiometer data, on 29 September the SST in the western central part decreased by more than $10^{\circ} \mathrm{C}$ (Fig. 1b), reaching an exceptionally low value for September of $10^{\circ} \mathrm{C}$. The maximum cooling was observed in the center of the cyclonic gyre in the southwestern part of the sea, where the SST fell to $10^{\circ} \mathrm{C}$, which was $13-15^{\circ} \mathrm{C}$ lower than the surrounding water SST $\left(23-25^{\circ} \mathrm{C}\right)$. In the Black Sea, the isotherm $10^{\circ} \mathrm{C}$ in September is located under the seasonal thermocline at depths of 30 $40 \mathrm{~m}$. Thus, the action of the QTC led to the rise of isopycnic surfaces by $30-40 \mathrm{~m}$ and the outcropping of deep isopycnal layers into the sea surface. Taking into account the active thermal mixing of waters due to the action of the cyclone and intense solar heating in this period of the year, it can be assumed that the waters were uplifted from even larger depths.

The Black Sea nutricline is relatively shallow, and its upper border is located at a depth of 50-60 m (Konovalov and Murray, 2001; Tuğrul et al., 2015). The euphotic zone in the Black Sea in September is about 40-50 m (Kubryakov et al., 2020). Thus, the impact of QTC caused an uplift of the nutricline from $30-40 \mathrm{~m}$ to the euphotic zone, accompanied by its erosion driven by strong wind mechanical mixing.

The action of the Ekman transport pushed the waters from the central part of the basin to its periphery, strongly increasing the sea level gradients over the Black Sea continental slope. In particular, the sea level on the western shelf of the basin rose by $20 \mathrm{~cm}$ from 0.2 to $0.4 \mathrm{~cm}$ (Fig. 2a, c). At the same time, in the western central part of the basin, the sea level dropped by $20 \mathrm{~cm}$ (Fig. 2a, c). The rise in sea level gradients caused a strong intensification of the large-scale cyclonic circulation of the Black Sea, i.e., the Rim Current. Its velocity over the continental slope increased, on average, twofold from the values of 0.25 to $0.45 \mathrm{~m} \mathrm{~s}^{-1}$ (Fig. $2 \mathrm{~b}$, d). The highest values of geostrophic velocity were recorded in the southwestern part of the sea, where they reached extremely high values for the Black Sea, exceeding $0.6 \mathrm{~m} \mathrm{~s}^{-1}$, with a maximum of $0.75 \mathrm{~m} \mathrm{~s}^{-1}$ (Fig. $2 \mathrm{~d}$ ).

The maximum intensity of the geostrophic velocity was observed about 2 weeks after the action of the cyclone on 6-10 October (Fig. 3; black line). This delay is related to the time needed for the sea level to adjust to the changes in Ekman transport. This time, as estimated from altimetry data, is 1-2 weeks (Grayek et al., 2010; Kubryakov et al., 2016), which is in close agreement with the time lag observed in the present case. As horizontal and vertical circulation are coupled, the same delay would be observed between the time of the cyclone action and the maximum upwelling. Thus, we might suggest that the vertical entrainment of nutrient-rich waters from deep layers also reaches its maximum 2 weeks after the QTC action.

\subsection{Impact of quasi-tropical cyclone on Chl}

Satellite measurements show that such changes in the basin dynamics significantly affected the bio-optical characteristics of the Black Sea. Before the passage of the atmospheric cyclone, the values of $\mathrm{Chl}$ in the central part of the basin were relatively low - less than $0.7-0.8 \mathrm{mg} \mathrm{m}^{-3}$ (see Figs. 3, 4). High values of Chl exceeding $3 \mathrm{mg} \mathrm{m}^{-3}$ at this time were observed in the northwestern shelf of the basin (red rectangle in Fig. 4a). The increase in $\mathrm{Chl}$ in this area is related to the dis- 

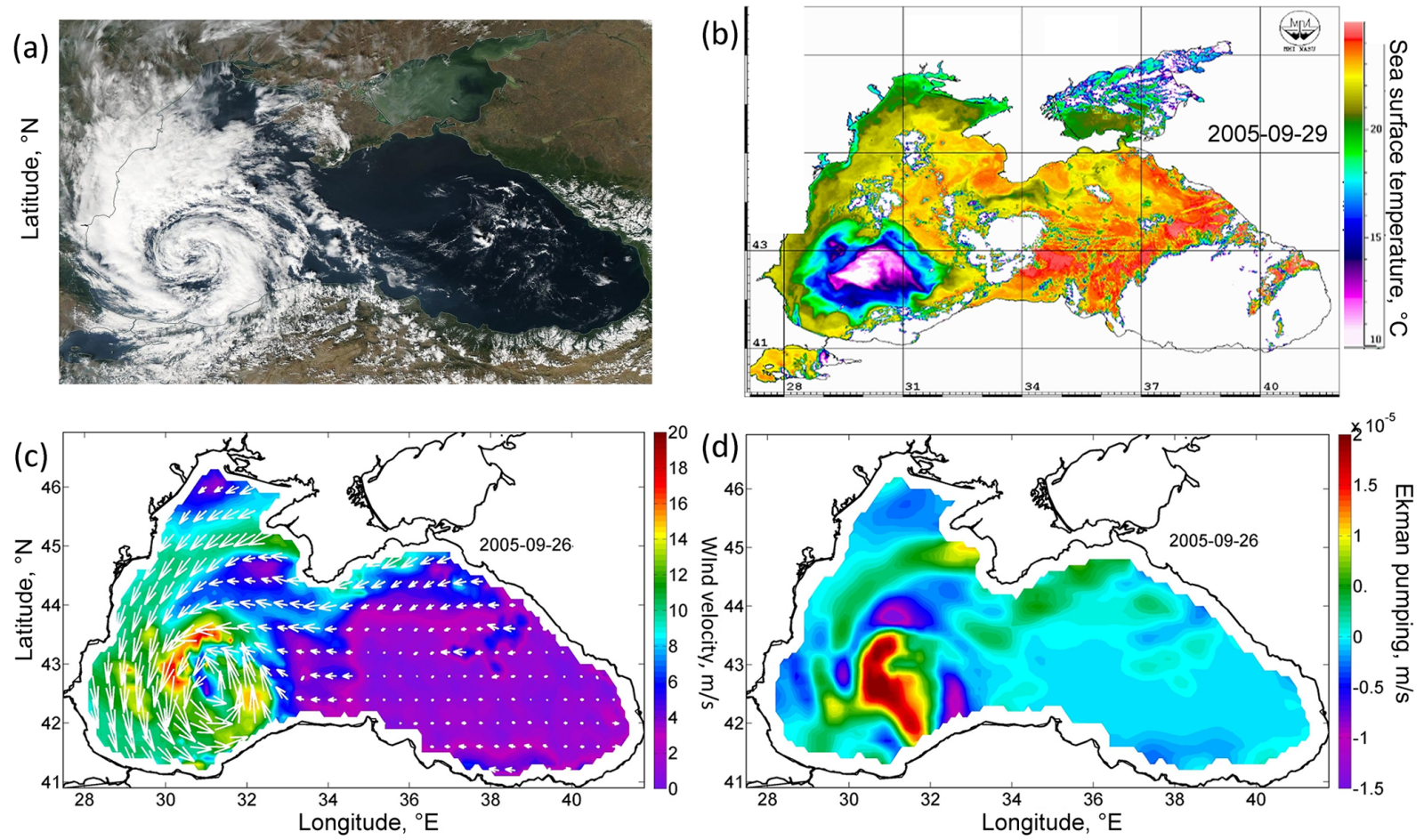

Figure 1. (a) Satellite image of MODIS Aqua in the visible range for 27 September 2005 (data obtained from the Worldview portal). (b) AVHRR SST (in degrees Celsius) for 29 September 2005. (c) Wind velocity (meters per second) of the scatterometer SeaWinds of the satellite QuikSCAT on 26 September 2005. (d) Ekman pumping velocity (meters per second) on 26 September 2005, calculated from QuikSCAT data (positive values indicate that the velocity is directed upwards).

charge of several rivers, with the major impact of the Danube plume (Yankovsky et al., 2004; Karageorgis et al., 2014). It should be noted that the Danube plume and shelf waters of the Black Sea correspond to turbid case 2 waters. The determination of the $\mathrm{Chl}$ in case 2 waters is a difficult task, and it is likely overestimated mainly due to the presence of colored dissolved organic matter. Therefore, for the description of the time variability of $\mathrm{Chl}$ in Fig. 3, we used only data in the central part of the basin. At the same time, increased values of Chl can be successfully used as a tracer of plume waters (see, for example, Sur et al., 1994, 1996; Kubryakov et al., 2018). At the beginning of September 2005, Danube waters with high satellite $\mathrm{Chl}$ occupied the northwestern part of the basin. The southern border of the plume was located in the southwestern part of the basin near $42^{\circ} \mathrm{N}$.

Immediately after the action of QTC in late September, $\mathrm{Chl}$ increased significantly in the western central part of the sea (red ellipse in Fig. 4b). Here, on 4 October, Chl reached relatively high values $\left(1.3 \mathrm{mg} \mathrm{m}^{-3}\right.$; green line in Fig. 3). However, in the next MODIS $8 \mathrm{~d}$ map (Fig. 4c), Chl in this zone decreased to the prestorm values. A possible reason for such rise in $\mathrm{Chl}$ is the entrainment of phytoplankton from its summer subsurface maximum, which causes its rapid, but short-term, increase in the surface layers (Babin et al., 2004; Kubryakov et al., 2019c).
QTC also significantly impacted on the propagation of the Danube plume waters. The intensified Rim Current transported the plume in the cyclonic direction from the southwestern part to the southern central coast (marked with the black arrow in Fig. 4b). On 5 October (Fig. 4b), the zone with high $\mathrm{Chl}\left(>3 \mathrm{mg} \mathrm{m}^{-3}\right)$ reached $34^{\circ} \mathrm{E}$. At this time, this zone looked like an alongshore band of high $\mathrm{Chl}$ values, with about $50 \mathrm{~km}$ width extending from the Danube mouth to the southern central coast of the Black Sea. Similar action from the Rim Current transport on the transfer of Danube plume to the southern part of the basin was documented in several previous studies (see, e.g., Özsoy and Ünlüata, 1997; Yankovsky et al., 2004; Kubryakov et al., 2018).

Significant intensification of the Rim Current in the southwestern Black Sea, up to extreme values of $0.75 \mathrm{~m} \mathrm{~s}^{-1}$, caused its baroclinic instability related to strong horizontal shear. The offshore boundary of the front of the turbid waters was characterized by several mesoscale features, i.e., eddies and filaments (see magnified MODIS map in Fig. 5a). These processes intensified the horizontal exchange in this part of the basin. As a result, on 12 October 2005, the area of the high Chl values in the southeastern part of the sea significantly widened and reached a width of $100-150 \mathrm{~km}$ (red dashed rectangle in Fig. 4c). The difference between the Chl maps in Fig. $4 \mathrm{~b}$ and $\mathrm{c}$ shows that, near the coast (in the 

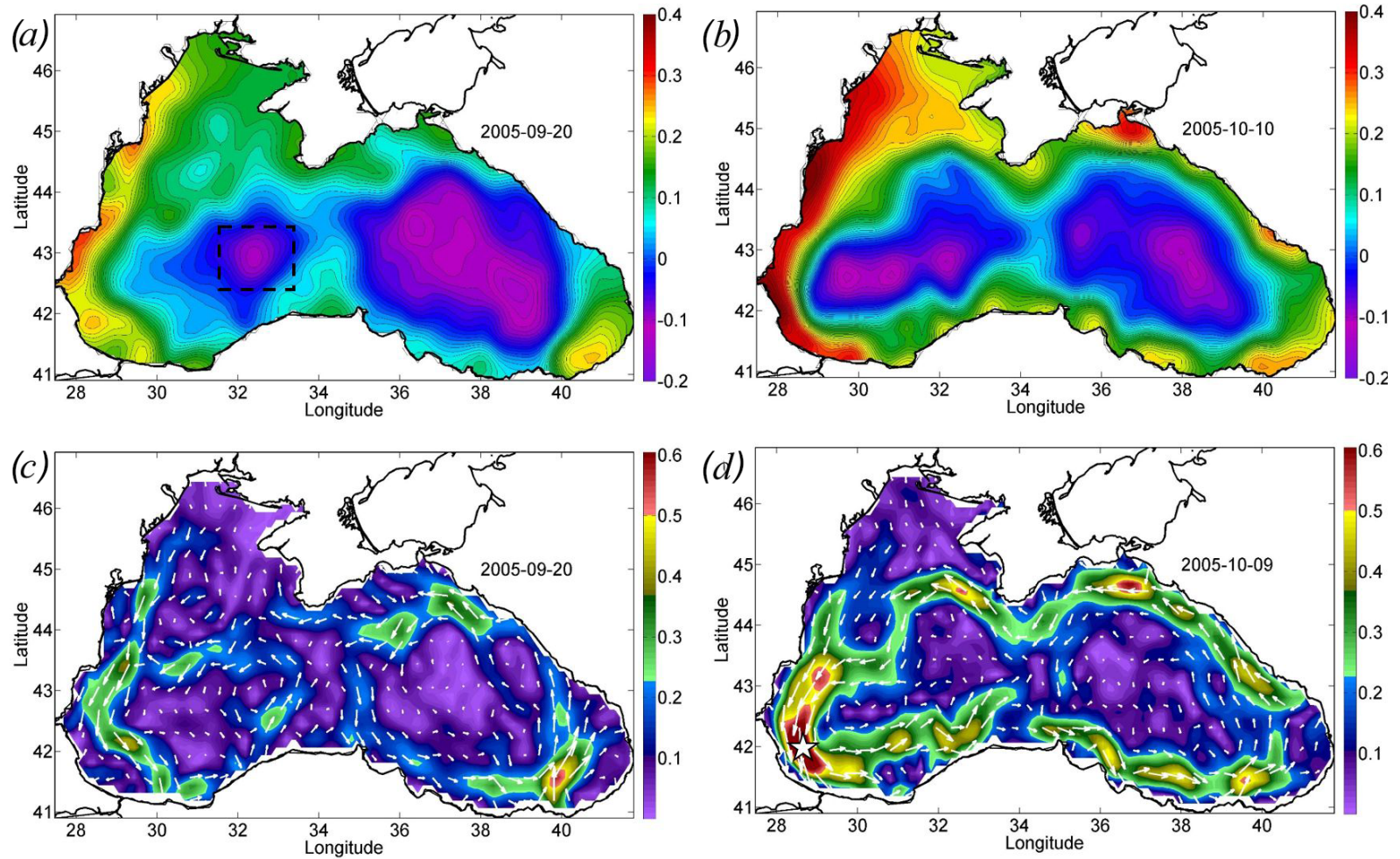

Figure 2. Altimetry-derived map of sea level and geostrophic velocity before (a, c) and after (b, d) the action of the cyclone. Sea level (meters) on (a) 20 September 2005 and (b) 10 October 2005. Geostrophic velocity (meters per second) on (c) 20 September 2005 and (d) 9 October 2005. The black rectangle in panel (a) shows the position of the western cyclonic gyre. Velocity magnitude (c, d) is shown by color scale.
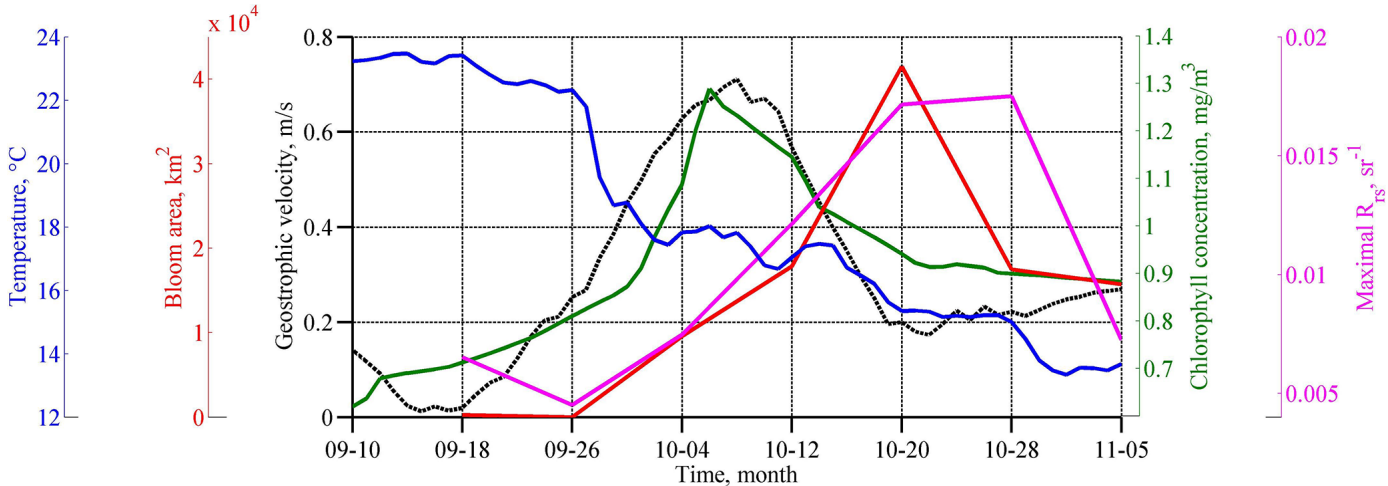

Figure 3. Temporal evolution of SST (degrees Celsius; blue line), $R_{\mathrm{rs}}$ (per steradian; purple line), and Chl (milligrams per cubic meter; green line) averaged in the western central part of the basin (see black rectangles in Fig. 5c, d), which is the area of coccolithophore bloom (square kilometers; red line) as computed only. Geostrophic velocity (meters per second; black dashed line) over the Black Sea continental slope is shown at the point $41.9375^{\circ} \mathrm{N}$ and $28.4375^{\circ} \mathrm{E}$; see the white star in Fig. $2 \mathrm{~d}$.

area of the red dashed rectangle), Chl decreased, while it increased to the north. It evidences the dilution of the plume due to its horizontal mixing with offshore waters with relatively low values of $\mathrm{Chl}\left(\mathrm{Chl}<0.75 \mathrm{mg} \mathrm{m}^{-3}\right)$. Such a distribution indicates that a significant part of the brackish and nutrient-rich plume water moved across the isobaths and penetrated in the southwestern central part of the sea. A week later, during 16-24 October, this wide zone of increased $\mathrm{Chl}$ $\left(\mathrm{Chl}>1.5 \mathrm{mg} \mathrm{m}^{-3}\right)$ disappeared, and the width of the plume decreased significantly (see Fig. 4d).

At this time, high values of $\mathrm{Chl}$ appeared in the western central part of the sea (Figs. 4d, 5c). The highest values of $\mathrm{Chl}$ (black circle in Fig. 4d; black rectangle in Fig. 5c) were located in the area of maximum upwelling in the western cy- 

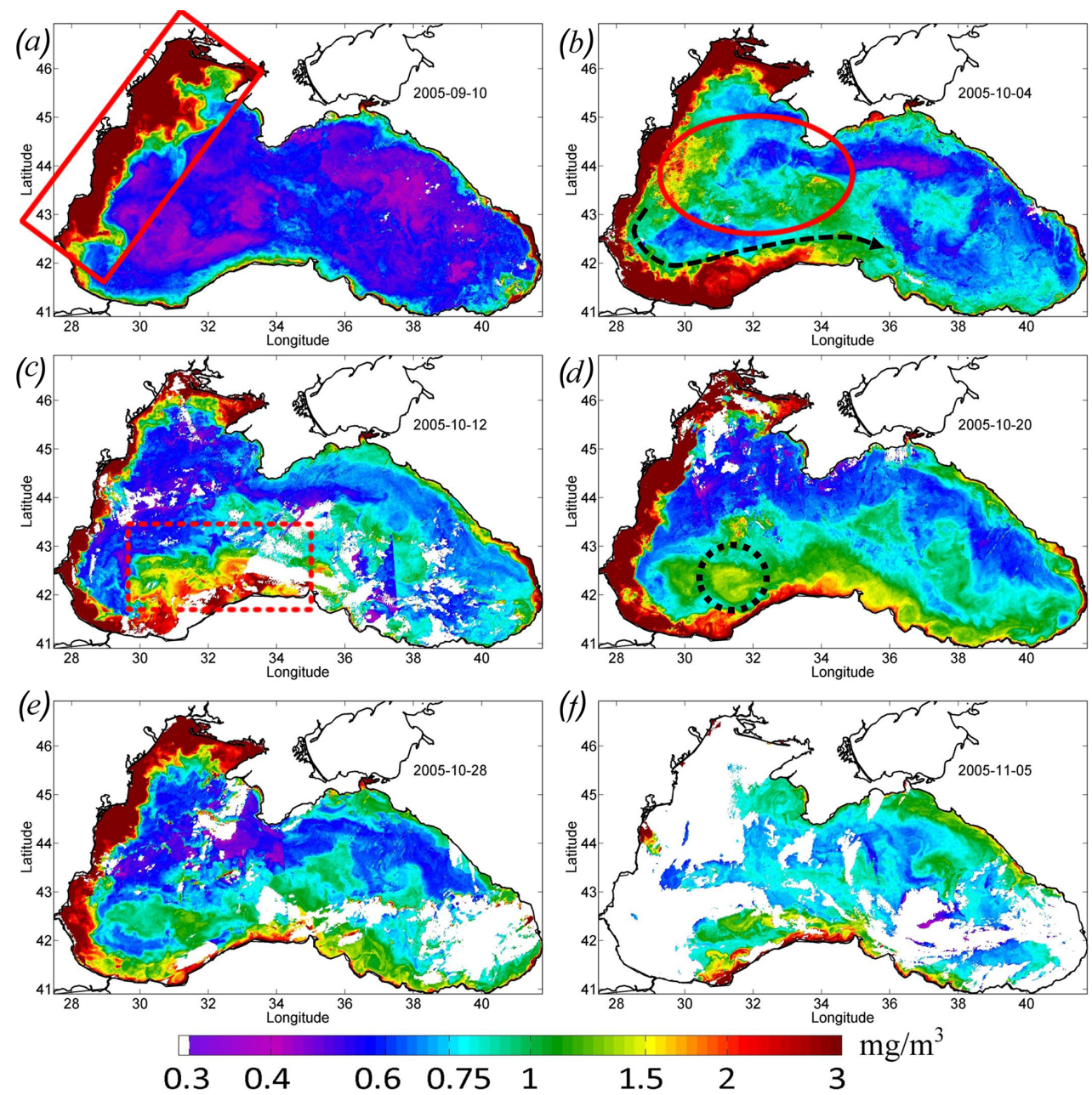

Figure 4. Maps of Chl concentration, in milligrams per cubic meter, over 8 d. (a) 10 September 2005 - the red rectangle (solid line) shows the position of the Danube plume. (b) 4 October 2005 - the red oval shows the zone of the rapid increase in Chl in the western central part of the basin. (c) 12 October 2005 - the red dashed rectangle shows the position of the cross-shelf mixing area. (d) 20 October 2005 - the black dashed circle shows the maximum $\mathrm{Chl}$ in the western cyclonic gyre. (e) 28 October 2005. (f) 5 November 2005.

clonic gyre, corresponding to the zone of minimal SST in Fig. 1b. Furthermore, waters with high Chl values were transported from this area by an intense Rim Current to the east. As a result, the region with high values of the Chl extended eastward along the continental slope up to the eastern coast of the basin to $41.5^{\circ} \mathrm{E}$ (Fig. $4 \mathrm{~d}$, e). In these areas, Chl increased to a value of $1-1.3 \mathrm{mg} \mathrm{m}^{-3}$, which was 2 times higher than in early September (Fig. 4d). At the end of October, Chl in the areas affected by the QTC began to decrease. It fell about twofold to the values of $0.75 \mathrm{mg} \mathrm{m}^{-3}$ (Fig. 4e).

At the beginning of November, $\mathrm{Chl}$ in the whole central part of the Black Sea rose again to $1 \mathrm{mg} \mathrm{m}^{-3}$ (Fig. 4f). This rise probably indicates the beginning of the late autumn phytoplankton bloom, which is associated with the deepening of a mixed layer to the upper border of the nutricline (Mikaelyan et al., 2018; Kubryakov et al., 2020).

\subsection{Impact of quasi-tropical cyclone on coccolithophores bloom}

The strongest impact of the cyclone was observed in the field of $R_{\mathrm{rs}}$. An exceptionally high rise in $R_{\mathrm{rs}}$ was observed in the western cyclonic gyre and southern deep part of the basin (Fig. 6a). The comparison of the $R_{\mathrm{rs}}$ map on 28 October 2005 with the climatic-averaged map for October 2003 2019 (Fig. 6a, b) demonstrates this anomalous event. Under normal conditions, $R_{\mathrm{rs}}$ in the Black Sea in October does not exceed $0.001 \mathrm{sr}^{-1}$, except in the area located near Danube mouth, the Kerch Strait, the most coastal area near the Caucasian rivers, and shallow northwestern shelf (see black rectangles in Fig. 6b). These areas are the source of lithogenic particles in the Black Sea caused by the riverine or Sea of Azov inflow, resuspension of bottom sediments, and coastal erosion (see Constantin et al., 2017; Aleskerovà et al., 2017, 2019; Kubryakov et al., 2019a). 

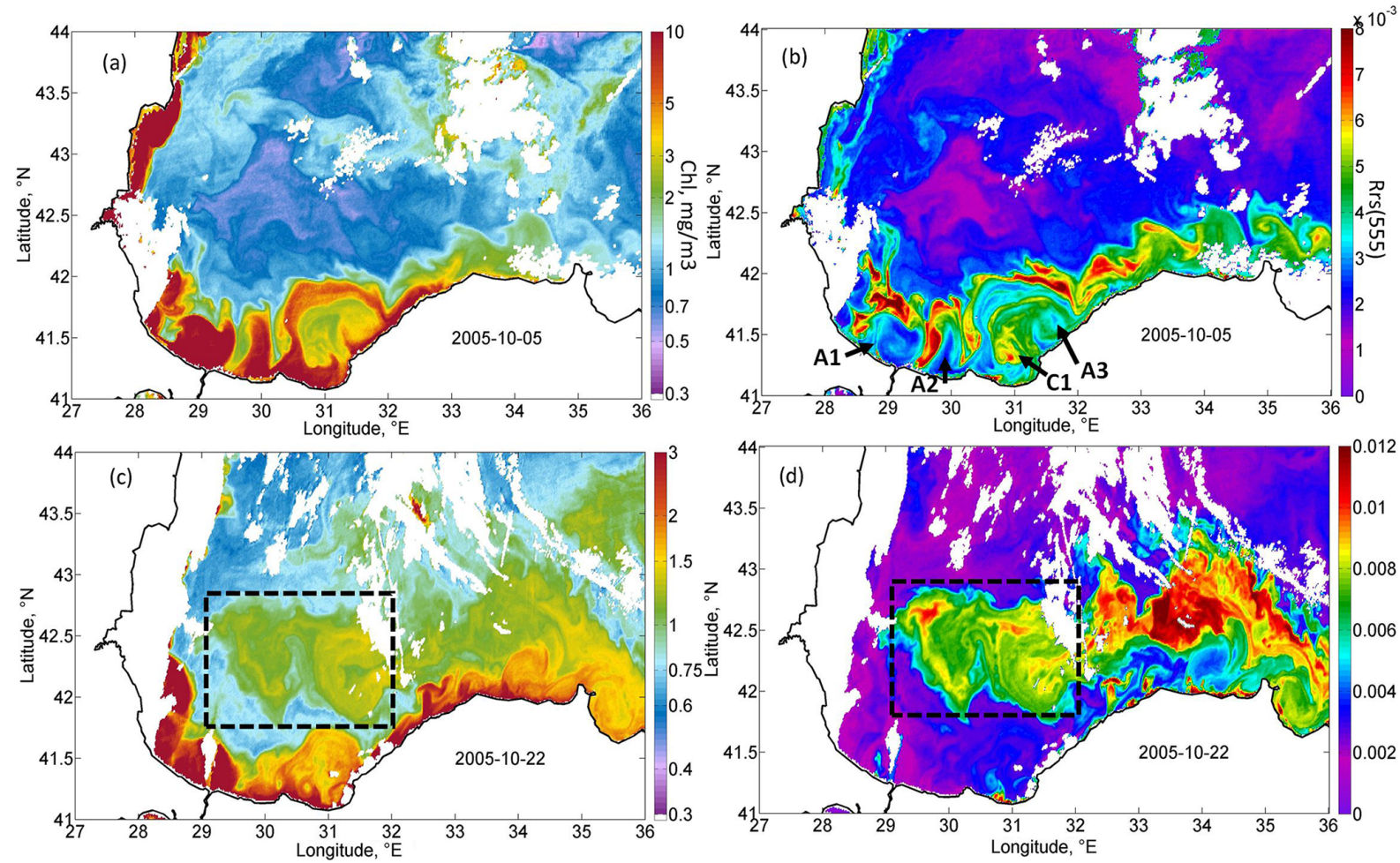

Figure 5. Magnified daily MODIS maps demonstrating the two stages of coccolithophore blooms development. MODIS daily map of Chl (a) and $R_{\mathrm{rs}}$ (b) on 5 October 2005, demonstrating the initial rise in $R_{\mathrm{rs}}$ on the offshore periphery of the Danube plume. MODIS daily map of Chl (c) and $R_{\mathrm{rs}}(\mathbf{d})$ on 22 October 2005, demonstrating the rise in $R_{\mathrm{rs}}$ in the western gyre of the Black Sea (black dashed rectangles).

A significantly different spatial distribution of $R_{\mathrm{rs}}$ was observed after the action of QTC. $R_{\mathrm{rs}}$ was highest - not near the coast or river mouths but in the deep western part of the basin, with depths of more than $1500 \mathrm{~m}$ over the southern continental slope. In this area, $R_{\mathrm{rs}}$ reached more than $0.010 \mathrm{sr}^{-1}$, which is 10 times higher than the climatological values.

In the southern part of the basin, there are several small rivers, but their plumes usually do not extend more than $10 \mathrm{~km}$ from their mouths (Kostianoy et al., 2019). In the considered cases (Fig. 6a), the width of high $R_{\mathrm{rs}}$ values near the southern part of the basin was about $100 \mathrm{~km}$. They were not located near a specific river mouth but extended over the whole periphery of the basin.

Therefore, the observed rise in $R_{\mathrm{rs}}$ should have a biological origin. In the Black Sea, such a rise in $R_{\mathrm{rs}}$ is often observed during coccolithophore blooms (Cokacar et al., 2001). The above arguments suggest that, in the presented case, we observe unusual coccolithophore blooms in October in the Black Sea.

The detailed evolution of $R_{\mathrm{rs}}$ in September-October 2005 is demonstrated in Fig. 7. Before the passage of the atmospheric cyclone, $R_{\mathrm{rs}}$ in the Black Sea was less than $0.004 \mathrm{sr}^{-1}$ (Fig. 7a). This value is typical for this season and indicates that the surface layer of the sea's central part contains a low concentration of particles that cause backscattering. The exception was the shallow northwestern shelf affected by the discharge of the major rivers.

In the western central part, $R_{\mathrm{rs}}$ was low until the action of the QTC (see the purple line in Fig. 3). At the beginning of October 2005, the rise in $R_{\mathrm{rs}}$ was first observed in the southwestern part of the sea (red rectangles in Fig. 7b). In this place, it increased to the values of $5-6 \times 10^{-3} \mathrm{sr}^{-1}$, corresponding to the level of the coccolithophore bloom. The initial rise in $R_{\mathrm{rs}}$ was detected in a limited area located over the southern continental slope of the basin to the south and west of the area of the QTC action. This increase was only observed on the shelf and/or slope boundary in the intermediate zone between the shelf and the central part (see red rectangles in Fig. 7b).

A detailed daily map of $R_{\mathrm{rs}}$ for 5 October 2005 (Fig. 5b) shows that the maximum $R_{\mathrm{rs}}$ was observed in the thin zone on the offshore periphery of the Danube plume. At the same time, near the coast and in the western central part in the epicenter of QTC action, high values of $R_{\mathrm{rs}}$ were absent at this time. This frontal zone is a subject of the intense horizontal mixing between brackish, nutrient-rich plume waters and the saline waters of the central part, which may be one of the possible triggers of the phytoplankton bloom. High $R_{\mathrm{rs}}$ values were located mainly in the frontal instabilities that 

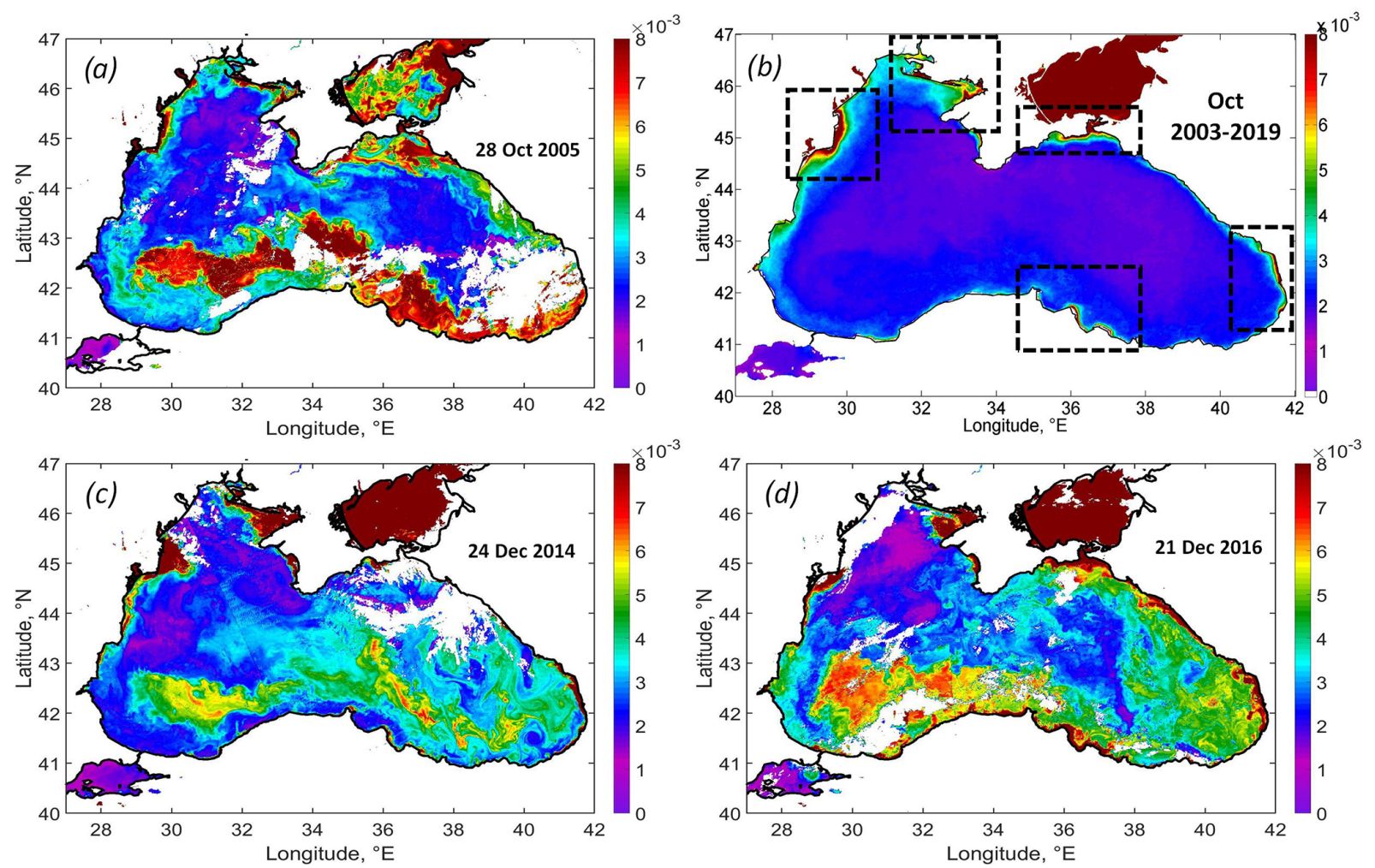

Figure 6. (a) MODIS $R_{\mathrm{rs}}$ map on 28 October 2005, showing the intense coccolithophore bloom developed after the action of the QTC. (b) Climatic $R_{\mathrm{rs}}$ map for October 2003-2019 (black rectangles show the main sources of the lithogenous articles in the Black Sea), similar to the case of the October 2005 coccolithophore blooms observed in the maps of $R_{\mathrm{rs}}$ on 24 December 2014 (c) and 21 December 2016 (d).

formed on the boundary of the plume. Such instabilities were possibly formed due to the impact of strong horizontal shear on the periphery of the intensified Rim Current. Mixing between the plume and saline waters additionally intensified buoyancy gradients and baroclinic submesoscale instabilities observed in Fig. 5a and b. Submesoscale motions can induce very strong vertical velocities, reaching more than 10 $100 \mathrm{~cm} \mathrm{~s}^{-1}$ (Mahadevan, 2016), which can provide intense upward nutrient fluxes. In the center of anticyclones (see, for example, anticyclones A1 and A2 in Fig. 5b), where vertical motions were directed downward, $R_{\mathrm{rs}}$ was low. At the same time, on their periphery, where vertical velocities are directed upward, a strong rise in $R_{\mathrm{rs}}$ was observed. Another prominent feature in Fig. $5 \mathrm{~b}$ is the mushroom structure consisting of cyclone $\mathrm{C} 1$ and anticyclone $\mathrm{A} 3$. The cyclonic part of this structure had significantly higher $R_{\mathrm{rs}}$ than its anticyclonic part. These observations suggest the important impact of submesoscale vertical fluxes in cyclonic structures on the initial rise in $R_{\mathrm{rs}}$. Analysis of MODIS daily maps showed that, in this area from 5 to 7 October 2005, the $R_{\mathrm{rs}}$ valued almost doubled. At the same time, $R_{\mathrm{rs}}$ was lower near the coast, which indicates that its rise was not related to the lithogenic particles caused by river discharge or storm-driven coastal erosion.
A week later, during $8-15$ October, $R_{\mathrm{rs}}$ rapidly increased (Fig. 7c) and the bloom area doubled (Fig. 3; red line). We note that the bloom area was estimated using only pixels in the deep part of the basin (depth of more than $500 \mathrm{~m}$ ) to exclude the impact of the lithogenic particles. The maximum $R_{\mathrm{rs}}$ increased to $0.012 \mathrm{sr}^{-1}$, which corresponded to $N=5.8 \times 10^{6}$ cells per liter. The area of the most intense bloom was observed over the continental slope south of the western gyre and the regions to the west of it (see the red rectangle in Fig. 7c). This distribution was very similar to the one observed in Chl (Fig. 4c, d).

In the next week (from 16 to 23 October), the bloom position shifted from the coast offshore to the center of the western gyre (Figs. 5d, 7d). The position of this gyre can be observed as an area of decreased SST (Fig. 1b) and low sea level (Fig. 2b) in satellite measurements. This area corresponded to the zone of maximal vertical mixing and intense vertical entrainment of nutrients from deep isopycnals layers. Here, a stable bloom area with a diameter of about $100 \mathrm{~km}$ developed (see black rectangles in Figs. 5d, 7d). At the same time, $R_{\mathrm{rs}}$ values in the southeastern coastal zone decreased to the background values.

Furthermore, the advection by the Rim Current transported both raised nutrients and already formed phytoplankton cells from the western central gyre to the east. The region of high 

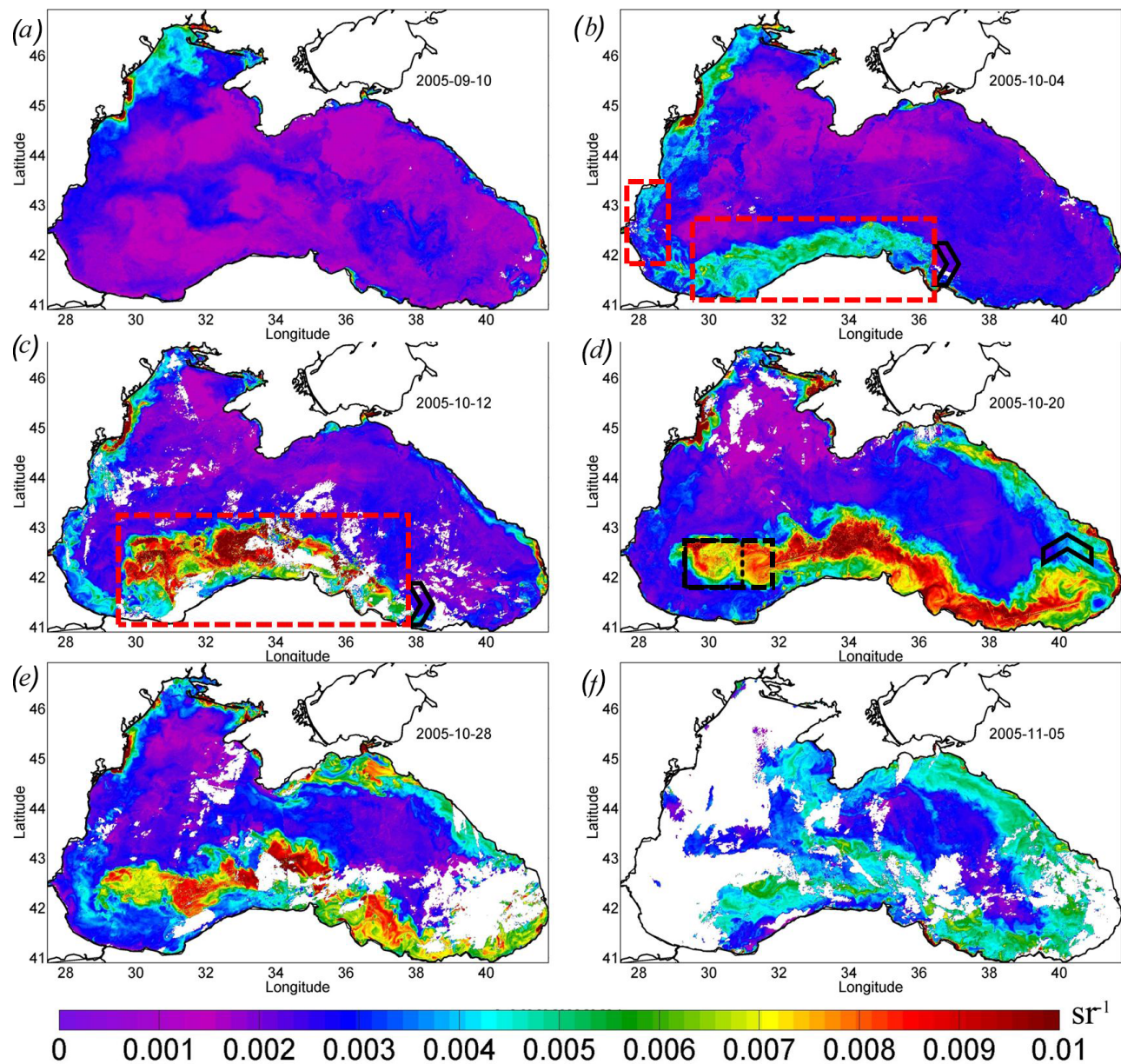

Figure 7. Maps of remote sensing reflectance $R_{\mathrm{rs}}$, per steradian, over 8 d. (a) 10 September 2005. (b) 4 October 2005 - the red rectangles show the area of the initial start of the bloom. (c) 12 October 2005 - the red rectangle shows a mixing area. (d) 20 October 2005 - the black rectangle shows the center of the deep bloom in the western cyclonic gyre. (e) 28 October 2005. (f) 5 November 2005. The black arrowhead $(\mathbf{b}, \mathbf{c}, \mathbf{d})$ shows the position of the eastern boundary of the bloom.

values of $R_{\mathrm{rs}}$ extended eastward from this area along the continental slope to the eastern coast of the basin up to $41.5^{\circ} \mathrm{E}$ (Fig. 7d, e). The black arrow in Fig. 7 marks the propagation of the eastward boundary of the plume. At the velocity of $0.45 \mathrm{~m} \mathrm{~s}^{-1}$ (Fig. 2d), the particles should be transported $1000 \mathrm{~km}$ in 3 weeks. Such transport caused the extension of the bloom up to the eastern coast of the Black Sea, which is in agreement with satellite optical measurements (Fig. 7e). As a result, the total length of the bloom area on 20 October 2005 was more than $1200 \mathrm{~km}$ (Fig. 7d).

The western boundary of the bloom was stationary and located in the center of the western cyclonic gyre (black rectangle in Fig. 7d). Therefore, the losses of coccolithophore cells caused by horizontal advection in this local zone were probably compensated by their growth due to intense vertical fluxes of nutrients. It indicates that the upwelling in the center of the western cyclonic gyre was a continuous source of nutrients for phytoplankton until the end of October, after which the bloom stretched to the eastern shore. Indeed, decreased SST in this area was observed until the end of October, indicating the stability of the upwelling. Such a prolonged duration of upwelling (2-3 weeks) can be related to the (1) delay between the action of Ekman pumping and upwelling and (2) the time needed for the relaxation of the upwelling after the wind action.

The average and maximum values of $R_{\mathrm{rs}}$ reached the highest values 2-3 weeks after the action of the QTC on 20 October 2005 (Fig. 3; purple line). At this time, in some areas of the central Black Sea (e.g., $43^{\circ} \mathrm{E}, 34^{\circ} \mathrm{N}$ ), $R_{\mathrm{rs}}$ was higher than $0.018 \mathrm{sr}^{-1}$, which corresponds to an estimate of $9-10 \times 10^{6}$ cells per liter. The bloom area reached a maximum of about $40 \times 10^{3} \mathrm{~km}^{2}$ (Fig. 3; red line).

At the end of October, the intensity of coccolithophore bloom in the western cyclonic cycle weakened (Fig. 7e). During this period, the maximum value of $R_{\mathrm{rs}}$ decreased to $0.007 \mathrm{sr}^{-1}$. At the beginning of November, $R_{\mathrm{rs}}$ fell to 0.005 $0.006 \mathrm{sr}^{-1}$, indicating the termination of the bloom (Fig. 7f). The termination occurred at the time of the beginning of the 
late autumn phytoplankton bloom, reflected in the rise in $\mathrm{Chl}$ over the whole central part of the basin (Fig. 4f).

\section{Discussion}

The action of the QTC caused a strong coccolithophore bloom in October 2005, which lasted for more than 1.5 months and covered the entire southern part of the Black Sea. Analysis of $R_{\mathrm{rs}}$ variability in 2003-2019 showed that this situation was unique for the early autumn period, when $R_{\mathrm{rs}}$ usually is low $\left(<0.002 \mathrm{sr}^{-1}\right.$; see Fig. 6b). Only in rare cases - in October 2006 and 2014 - do we observe the increase in $R_{\mathrm{rs}}$ up to $0.005 \mathrm{sr}^{-1}$, which still 2 times lower than $0.010 \mathrm{sr}^{-1}$ in 2005. Somewhat similar to October 2005, blooms were observed in satellite data in December 2014 and 2016 (Fig. 6c, d). These figures demonstrate similar spatial patterns of $R_{\mathrm{rs}}$ extending from the western cyclonic gyre over the southern continental slope. Such winter blooms were also triggered by intense western storms (see Kubryakova et al., 2021) over the western cyclonic gyre. These illustrations show that the processes discussed in this paper may define the biological characteristics of the basin in other years. However, in both of these cases, $R_{\mathrm{rs}}$ was smaller than in 2005 and usually does not exceed 0.007 (compared to $0.01 \mathrm{sr}^{-1}$ in 2005). Also, such blooms were observed later in winter, in December, which is the month that is characteristic of winter coccolithophore blooms (Kubryakova et al., 2021).

Such an analysis demonstrates that, in October 2005, we observed an exceptional situation in the Black Sea, i.e., the early autumn bloom of coccolithophores with estimated cell concentrations exceeding $10 \times 10^{6}$ cells per liter. This situation was caused by the action of the anomalous, extremely strong QTC in September 2005. Unfortunately, currently there is no in situ microscopic information about coccolithophore blooms and, especially, their time evolution after intense atmospheric storms. The results of this study showed that such processes could significantly impact on the taxonomic composition of the phytoplankton and deserve a specialized in situ investigation.

The phytoplankton bloom in the autumn-winter period in the Black Sea is related to the vertical entrainment of nutrients from their subsurface maximum. Usually, this process causes a rapid growth of diatoms in November-December (Sorokin, 1983; Mikaelyan et al., 2017; Silkin et al., 2019; Kubryakov et al., 2020), which have a higher growth rate than the coccolithophores (Goldman, 1993; Lomas and Glibert, 1999). Several authors demonstrated the rapid increase of $\mathrm{Chl}$ in the Black Sea after strong storm events in summer (Nezlin, 2006; Kubryakov et al., 2019c) and the autumn period (Mikaelyan et al., 2017, 2020). However, in October 2005, we observed another case - the atmospheric cyclone caused only a slight rise in $\mathrm{Chl}$, which was followed by the very strong coccolithophore blooms (see Fig. 3).
There are several possible reasons for such intense coccolithophore blooms in the observed case. Very intense upwelling and wind mixing caused the entrainment of a huge amount of nutrients from the nutricline. These layers of the Black Sea are characterized by a low N/P ratio, which is about 2-6 (Konovalov et al., 2005; Tuğrul et al., 2014). Low $\mathrm{N} / \mathrm{P}$ is caused by the intense removal of nitrates through a denitrification process in the suboxic layer of the basin (Konovalov et al., 2008; Tuğrul et al., 2014; Yakushev et al., 2007). Nitrates entrained to the surface are first rapidly consumed by diatoms, which have a higher growth rate than coccolithophores (Goldman, 1993). This process caused the increase in Chl, which reached its peak 1 week after the QTC (Fig. 3). However, as the N/P ratio (2-6) was significantly smaller than the Redfield ratio (16), part of the phosphate remained in the upper layer. Due to lower growth rates of coccolithophores, the observed rise in $R_{\mathrm{rs}}$ was more gradual. A total of 2-3 weeks after the QTC, Chl decreased to its prestorm values. The decrease in $\mathrm{Chl}$ indicates the termination of the bloom, due to mortality or grazing, and the transformation of nutrients in the organic form. According to Stelmakh et al. (2009), the lysis of the organic matter by small diatoms in the final stage of their bloom promotes the growth of Emiliania huxleyi in the Black Sea. Coccolithophores can use osmotrophy and utilize dissolved organic nitrogen (Balch., 2018; Benner and Passow, 2010; Poulton et al., 2017). Emiliania huxleyi contain several specific enzymes and proteins, which may switch their diet from inorganic to organic (Dyhrman and Palenik, 2003). A large amount of the remaining phosphates and organic nitrogen caused the maximum development of the coccolithophore blooms 3-4 weeks after the QTC. Such a situation is usually observed in the Black Sea in spring, when the winter convection is followed by the intense spring bloom of diatoms in March, and then, by May-June, the coccolithophores bloom (Mikaelyan et al., 2015; Kubryakov et al., 2019c). The hypothesis explaining the observed diatom-coccolithophore sequence in the Black Sea was proposed in Mikaelyan et al. (2015) and is supported by the in situ chemical and biological data of Mikaelyan et al. (2015) and Silkin et al. (2009, 2014).

Long-term analysis of MODIS data in 2003-2019 (Kubryakova et al., 2021) showed that winter coccolithophore blooms are also often observed 1-2 weeks after intense storm action. According to Kubryakova et al. (2021), such blooms were especially strong in years with increased cross-shelf exchange. A possible reason for such a relation is the grazing pressure by zooplankton on diatoms. Shelf waters of the Black Sea are characterized by a high concentration of zooplankton, which can exceed its concentrations in the deep part of the basin by 10 times (Kovalev et al., 1999). The grazing pressure on the diatoms or dinoflagellates by zooplankton is usually higher than on coccolithophores (Nejstgaard, 1997; Stelmakh, 2013), which may give them an advantage during high concentrations of predators. Stelmakh (2013) showed that, in the Black Sea, grazing in diatom-dominated regions 
was about $90 \%$, while in coccolithophore-dominated regions it was 3 times lower (30\%), which is in agreement with estimates obtained by Olson and Strom (2002).

The largest seasonal peak of zooplankton in the Black Sea is observed in September-October (Kovalev et al., 2003; Stelmakh, 2013). Therefore, QTC was observed during a seasonal maximum of zooplankton. QTC caused an intense cross-shelf exchange (see Fig. 5), which promoted the additional penetration of zooplankton from the shelf to the central part of the basin. All of the above processes may suppress the rise in diatoms, despite the strong nutrients fluxes, and may give an advantage to coccolithophores.

The initial rise in $R_{\mathrm{rs}}$ was observed at the frontal zone separating the brackish, nutrient-rich waters of the Danube plume and saline waters of the central Black Sea. The acceleration of the Rim Current up to extreme velocities of $0.75 \mathrm{~m} \mathrm{~s}^{-1}$ caused an increase in horizontal and vertical shear. The vertical shear of the Rim Current is one of the important reasons for the rise in the vertical turbulent mixing (see Ostrovskii and Zatsepin, 2016; Podymov et al., 2020). The rise in horizontal shear also triggered the formation of several submesoscale eddies (see Fig. 5) in the coastal zone of the Black Sea (Zatsepin et al., 2019). These eddies intensified the cross-shelf exchange and the horizontal transport of Danube plume waters in the deep part of the basin. Danube plume waters are rich in organic and inorganic nutrients (Saliot et al., 2002; Kondratev et al., 2015, 2019). The mixing zone became the first area in which coccolithophores started to grow up to bloom conditions. The overflow of the brackish plume in the saline waters additionally increases the baroclinic instabilities (Luo et al., 2016) and intensifies submesoscale motions. Recent studies demonstrated that such processes could cause very intense vertical motions, which may be an important reason for the rise in the primary productivity on the fronts (Oguz et al., 2015; Mahadevan, 2016). Such submesoscale vertical fluxes can explain the spatial distribution of $R_{\mathrm{rs}}$ in Fig. 5a and also help to explain its earlier rise compared to the central part of the basin. Therefore, a cross-frontal mixing may cause the initial growth of coccolithophores due to the following reasons: (1) vertical fluxes of nutrients caused by baroclinic submesoscale instabilities, (2) penetration of nutrients or dissolved organics from brackish plume waters in the deep saline part of the basin, and (3) penetration of zooplankton from the shelf, which suppresses the growth of other types of phytoplankton.

The most intense coccolithophore blooms in the Black Sea are observed in May-June. During this period, the cell concentration is usually $N=2-6 \times 10^{6}$ cells per liter (Mikaelyan et al., 2011, 2015), which is $2-4$ times higher than in weaker winter blooms $\left(N=0.5-2 \times 10^{6}\right.$ cells per liter; Kubryakova et al., 2021). The coccolithophore blooms usually occupy the upper mixed layer, which is $2-3$ times larger in winter than in summer, which suggests that the total cell amount in the water column is similar in the winter and summer period (Kubryakov et al., 2019b). In Oc- tober 2005, we observed very high surface values of $R_{\mathrm{rs}}$, reaching $0.018 \mathrm{sr}^{-1}$, which correspond to the estimated $N$, reaching $10 \times 10^{6}$ cells per liter. The mixed layer in October is usually about 2 times higher than in early summer, which suggests that the intensity of the observed autumn coccolithophore bloom in October 2005 was comparable to the record blooms detected in the summers of 1993 (Mihnea, 1997) and 2012 (Yasakova and Stanichny, 2012).

\section{Conclusions}

The action of the QTC in September 2005 caused an intense bloom of coccolithophore in the Black Sea basin, with the satellite-estimated concentration reaching $10 \times 10^{6}$ cells per liter. Satellite data showed that the bloom was caused by intense upwelling driven by Ekman pumping during the action of QTC. The upwelling was highest in the western cyclonic gyre of the Black Sea, where isopycnals were uplifted to the surface. After QTC, SST in this area decreased to $10^{\circ} \mathrm{C}$, which was $10-13^{\circ} \mathrm{C}$ lower than surrounding waters, indicating intense vertical entrainment of nutrients in the euphotic layer. This process led to the increase in $\mathrm{Chl}$, which was followed by a strong bloom of coccolithophores. The bloom was continuously observed in the area of upwelling in the western cyclonic gyre for more than 1.5 months. An intense cyclonic Rim Current spread the bloom from this permanent source of nutrients, and at the end of October, the bloom covered the entire southern part of the Black Sea.

The initial growth of coccolithophores after the QTC was observed in the frontal zone between the central part of the Black Sea and the plume of the Danube. Rapid intensification of the Rim Current after the QTC led to the intense cross-shelf mixing of these waters, accompanied by the generation of a number of submesoscale instabilities. The initial growth of $R_{\mathrm{rs}}$ was detected in these submesoscale structures of cyclonic signs, which indicate that intense vertical motions in frontal submesoscale cyclones were another important source of the nutrients for the coccolithophore blooms during its initial stage.

In addition to the aforementioned physical mechanisms, there were several biological factors underlying the observed phenomenon, including (a) higher grazing pressure on the other phytoplankton (such as diatoms) by zooplankton, which has its seasonal maximum in September-October, the (b) ability of coccolithophores to use osmotrophy and utilize organic nitrogen, and a (c) low N/P ratio in the Black Sea nutricline, which led to the fast depletion of nitrates for diatoms blooms.

As described here, extreme atmospheric events can play an important role in the observed interannual variability in the coccolithophores and related carbonate fluxes in many other ocean areas, such as the North Atlantic and the Southern Ocean, where storms are significantly more frequent. Such coccolithophore blooms may significantly impact the sea- 
sonal succession of marine phytoplankton. Particularly, they can trigger the following microbial loop - the transition of trophic energy to small species and subsequent changes in the entire trophic structure of the region (Brussaard, 2004; Kubryakov et al., 2019b). For a further detailed investigation of the response of the phytoplankton community to short-term physical processes, continuous data on the taxonomic composition of phytoplankton, based, for example, on the measurements of moored-flow cytometers, are required. These data are also crucial for the validation of regional satellite algorithms for phytoplankton species detection (Bracher et al., 2017) and biogeochemical numerical models, which will help to provide more insights into the mechanisms of the ecosystem response to intense atmospheric forcing.

Data availability. We acknowledge the use of the (1) Moderate Resolution Imaging Spectroradiometer (MODIS) Aqua Ocean Color Data produced by the NASA Goddard Space Flight Center (https://doi.org/10.5067/AQUA/MODIS/L2/OC/2018, NASA Goddard Space Flight Center, 2018). (2) Data Unification and Altimeter Combination System (DUACS) delayed-time altimeter gridded maps of sea level anomalies over the Black Sea (https://resources. marine.copernicus.eu/?option=com_csw\&view=details\&product id=SEALEVEL_BS_PHY_L4_REP_OBSERVATIONS_008_042, Copernicus Climate Change Service, 2021) produced and distributed by the Copernicus Climate Change Service. QuikSCAT (or SeaWinds) data are produced by remote sensing systems and sponsored by the NASA Ocean Vector Winds Science Team and are available at http://www.remss.com/missions/qscat/ (Ricciardulli et al., 2011). Advanced Very-High-Resolution Radiometer (AVHRR) data were received and reprocessed at the Marine Hydrophysical Institute, Russia, and are available from http://dvs.net.ru/mp/data/200509bs_sst.shtml (Remote Sensing Department, 2021).

Author contributions. SVS and AAK were involved in planning and supervising the work. EAK and AAK processed the satellite data and performed the analysis, EAK drafted the paper and designed the figures. All authors discussed the results and commented on the paper.

Competing interests. The authors declare that they have no conflict of interest.

Acknowledgements. Data acquisition and processing were made possible with the support of the Russian Foundation for Basic Research (grant no. 19-05-00752). The study of the impact of a tropical cyclone on the phytoplankton bloom development was supported by the Russian Science Foundation (grant no. 20-17-00167). Investigation of the evolution of autumn coccolithophore bloom was supported by Russian Foundation for Basic Research (grant no. 20-3570034). Tropical cyclone analysis was supported by the government of Russia (grant no. 0555-2021-0003).
Financial support. This research has been supported by the Russian Science Foundation (grant no. 20-17-00167), the Russian Foundation for Basic Research (grant nos. 19-05-00752 and 20-3570034), and the Russian government assignment (grant no. 05552021-0003).

Review statement. This paper was edited by Marilaure Grégoire and reviewed by three anonymous referees.

\section{References}

Aleskerovà, A. A., Kubryakov, A. A., Goryachkin, Y. N., and Stanichny, S. V.: Propagation of waters from the Kerch Strait in the Black Sea, Physical Oceanography, 6, 47-57, https://doi.org/10.22449/1573-160X-2017-6-47-57, 2017.

Aleskerovà, A. A., Kubryakov, A. A., Goryachkin, Y. N., Stanichny, S. V., and Garmashov, A. V.: Suspended-Matter Distribution Near the Western Coast of Crimea under the Impact of Strong Winds of Various Directions, Izv. Atmos. Ocean. Phy.+, 55, 1138-1149, https://doi.org/10.1134/S0001433819090044, 2019.

Babin, S. M., Carton, J. A., Dickey, T. D., and Wiggert, J. D.: Satellite evidence of hurricane-induced phytoplankton blooms in an oceanic desert, J. Geophys. Res.-Oceans, 109, C03043, https://doi.org/10.1029/2003JC001938, 2004.

Balch, W. M.: The ecology, biogeochemistry, and optical properties of coccolithophores, Annu. Rev. Mar. Sci., 10, 71-98, https://doi.org/10.1146/annurev-marine-121916-063319, 2018.

Balch, W. M., Holligan, P. M., Ackleson, S. G., and Voss, K. J.: Biological and optical properties of mesoscale coccolithophore blooms in the Gulf of Maine, Limnol. Oceanogr., 36, 629-643, https://doi.org/10.4319/lo.1991.36.4.0629, 1991.

Balch, W. M., Kilpatrick, K. A., and Trees, C. C.: The 1991 coccolithophore bloom in the central North Atlantic, 1. Optical properties and factors affecting their distribution, Limnol. Oceanogr., 41, 1669-1683, 1996.

Balch, W. M., Drapeau, D. T., Bowler, B. C., Lyczskowski, E., Booth, E. S., and Alley, D.: The contribution of coccolithophores to the optical and inorganic carbon budgets during the Southern Ocean Gas Exchange Experiment: New evidence in support of the "Great Calcite Belt" hypothesis, J. Geophys. Res.-Oceans, 116, C00F06, https://doi.org/10.1029/2011JC006941, 2011.

Benner, I. and Passow, U.: Utilization of organic nutrients by coccolithophores, Mar. Ecol. Prog. Ser., 404, 21-29, https://doi.org/10.3354/meps08474, 2010.

Bracher, A., Bouman, H. A., Brewin, R. J., Bricaud, A., Brotas, V., Ciotti, A. M., Clementson, L., Devred, E., Cicco, A.D., Dutkiewicz, S., Hardman-Mountford, N. J., Hickman, A. E., Hieronymi, M., Hirata, T., Losa, S. N., Mouw, C. B., Organelli, E., Raitsos, D. E., Uitz, J., Vogt, M., and Wolanin A.: Obtaining phytoplankton diversity from ocean color: a scientific roadmap for future development, Frontiers in Marine Science, 4, 55, https://doi.org/10.3389/fmars.2017.00055, 2017.

Brussaard, C. P. D.: Viral control of phytoplankton populations - a review, J. Eukaryot. Microbiol., 51, 125-138, https://doi.org/10.1111/j.1550-7408.2004.tb00537.x, 2004.

Chacko, N.: Chlorophyll bloom in response to tropical cyclone Hudhud in the Bay of Bengal: Bio-Argo sub- 
surface observations, Deep-Sea Res. Pt. I, 124, 66-72, https://doi.org/10.1016/j.dsr.2017.04.010, 2017.

Cokacar, T., Kubilay, N., and Oguz, T.: Structure of Emiliania huxleyi blooms in the Black Sea surface waters as detected by SeaWiFS imagery, Geophys. Res. Lett., 28, 4607-4610, https://doi.org/10.1029/2001GL013770, 2001.

Cokacar, T., Oguz, T., and Kubilay, N.: Satellite-detected early summer coccolithophore blooms and their interannual variability in the Black Sea, Deep-Sea Res. Pt. I, 51, 1017-1031, https://doi.org/10.1016/j.dsr.2004.03.007, 2004.

Constantin, S., Constantinescu, S., and Doxaran, D.: Long-term analysis of turbidity patterns in Danube Delta coastal area based on MODIS satellite data, J. Marine Syst., 170, 10-21, https://doi.org/10.1016/j.jmarsys.2017.01.016, 2017.

Coolen, J.: 7000 years of Emiliania huxleyi viruses in the Black Sea, Science, 333, 451-452, https://doi.org/10.1126/science.1200072, 2011.

Copernicus Climate Change Service: Data Unification and Altimeter Combination System (DUACS) delayed-time altimeter gridded maps of sea level anomalies over the Black Sea, available at: https://resources.marine.copernicus.eu/?option=com csw\&view=details\&product_id=SEALEVEL_BS_PHY_L4_ REP_OBSERVATIONS_008_042, last access: 11 May 2021.

Dyhrman, S. T. and Palenik, B.: Characterization of ectoenzyme activity and phosphate-regulated proteins in the coccolithophorid Emiliania huxleyi, J. Plankton Res., 25, 12151225 , https://doi.org/10.1093/plankt/fbg086, 2003.

Efimov, V. V., Shokurov, M. V., and Yarovaya, D. A.: Numerical Simulation of a Quasi-Tropical Cyclone over the Black Sea, Izv. Atmos. Ocean. Phy.+, 43, 667-686, https://doi.org/10.1134/S0001433807060011, 2007.

Efimov, V. V., Stanichnyi, S. V., Shokurov, M. V., and Yarovaya, D. A.: Observations of a quasi-tropical cyclone over the Black Sea, Russ. Meteorol. Hydrol., 33, 233-239, https://doi.org/10.3103/S1068373908040067, 2008.

Efimov, V. V., Shokurov, M. V., Yarovaya, D. A., and Hein, D.: Statistics of mesoscale cyclonic eddies over the Black Sea, Physical Oceanography, 19, 211, https://doi.org/10.1007/s11110-0099052-8, 2009.

Emanuel, K.: Tropical Cyclones, Annu. Rev. Earth Planet. Sci., 31, 75104, https://doi.org/10.1146/annurev.earth.31.100901.141259, 2003.

Goldman, J. C.: Potential role of large oceanic diatoms in new primary production, Deep-Sea Res., 40, 159-168, https://doi.org/10.1016/0967-0637(93)90059-C, 1993.

Gordon, H. R. and Balch, W. M. (Eds.): MODIS detached coccolith concentration, in: MODIS Algorithm Theoretical Basis Document, University of Miami, Miami, Florida, USA, 27 pp., 1999.

Grayek, S., Stanev, E. V., and Kandilarov, R.: On the response of Black Sea level to external forcing: altimeter data and numerical modelling, Ocean Dynam., 60, 123-140, https://doi.org/10.1007/s10236-009-0249-7, 2010.

Han, G., Ma, Z., and Chen, N.: Hurricane Igor impacts on the stratification and phytoplankton bloom over the Grand Banks, J. Marine Syst., 100, 19-25, https://doi.org/10.1016/j.jmarsys.2012.03.012, 2012.

Hay, B. J., Honjo, S., Kempe, S., Ittekkot, V. A., Degens, E. T., Konuk, T., and Izdar, E.: Interannual variability in particle flux in the south-western Black Sea, Deep-Sea Res., 37, 911-928, https://doi.org/10.1016/0198-0149(90)90103-3, 1990.

Holligan, P. M., Viollier, M., Harbour, D. S., Camus, P., and Champagne-Philippe, M.: Satellite and ship studies of coccolithophore production along a continental shelf edge, Nature, 304, 339-342, https://doi.org/10.1038/304339a0, 1983.

Homar, V., Romero, R., Stensrud, D. J., Ramis, C., and Alonso, S.: Numerical diagnosis of a small, quasi-tropical cyclone over the western Mediterranean: Dynamical vs. boundary factors, Q. J. Roy. Meteor. Soc., 129, 1469-1490, https://doi.org/10.1256/qj.01.91, 2003.

Honjo, S.: Coccoliths: production, transportation and sedimentation, Mar. Micropaleontol., 1, 65-79, https://doi.org/10.1016/0377-8398(76)90005-0, 1976.

Hopkins, J., Henson, S. A., Painter, S. C., Tyrrell, T., and Poulton, A. J.: Phenological characteristics of global coccolithophore blooms, Global Biogeochem. Cy., 29, 239-253, https://doi.org/10.1002/2014GB004919, 2015.

Ivanov, V. A. and Belokopytov, V. N. (Eds.): Oceanography of the Black Sea, ECOSY-Gidrofizika, Sevastopol, Crimea, 215 pp., 2013.

Karageorgis, A. P., Gardner, W. D., Mikkelsen, O. A., Georgopoulos, D., Ogston, A. S., Assimakopoulou, G., Krasakopoulou, E., Oaie, G., Secrieru, D., Kanellopoulos, T. D., Pagou, K., Anagnostou, C., and Papathanassiou, E.: Particle sources over the Danube River delta, Black Sea based on distribution, composition and size using optics, imaging and bulk analyses, J. Marine Syst., 131, 74-90, https://doi.org/10.1016/j.jmarsys.2013.11.013, 2014

Kondratev, S. I.: Peculiarities of Nutrients Distribution in the Coastal Waters near the Danube Estuary in 1997-2013, Physical Oceanography, 5, 3248, https://doi.org/10.22449/1573-160X2015-5-32-48, 2015.

Kondratev, S. I.: Three Typical Hydrological-Hydrochemical Situations Near the Danube River Mouth Based on the Marine Hydrophysical Institute Research Expeditions in 1997-2013, Physical Oceanography, 26, 326-340, https://doi.org/10.22449/1573160X-2019-4-326-340, 2019.

Konovalov, S. K. and Murray, J. W.: Variations in the chemistry of the Black Sea on a time scale of decades (1960-1995), J. Marine Syst., 31, 217-243, https://doi.org/10.1016/S09247963(01)00054-9, 2001.

Konovalov, S. K., Murray, J. W., and Luther III, G. W.: Black Sea Biogeochemistry, Oceanography, 18, 24-35, 2005.

Konovalov, S. K., Fuchsman, C. A., Belokopitov, V., and Murray, J. W.: Modeling the distribution of nitrogen species and isotopes in the water column of the Black Sea, Mar. Chem., 111, 106-124, https://doi.org/10.1016/j.marchem.2008.01.006, 2008

Kopelevich, O., Burenkov, V., Sheberstov, S., Vazyulya, S., Kravchishina, M., Pautova, L., Silkin, V., Artemiev, V., and Grigoriev, A.: Satellite monitoring of coccolithophore blooms in the Black Sea from ocean color data, Remote Sens. Environ., 146, 113-123, https://doi.org/10.1016/j.rse.2013.09.009, 2014.

Korchemkina, E. N. and Lee, M. E.: The anomalous optical characteristics of the Black Sea waters in July 2012 and their relationship to the concentration of mineral suspended matter in the water, Marine Hydrophysical Journal, 2, 67-72, 2014 (in Russian). 
Kostianoy, A. G., Lebedev, S. A., Soloviev, D. M., and Tepe, Y.: On river plumes along the Turkish coast of the Black Sea, Ecologica Montenegrina, 25, 63-78, https://doi.org/10.37828/em.2019.25.7, 2019.

Kovalev, A. V., Skryabin, V. A., Zagorodnyaya, Y. A., Bingel, F., Kideyş, A. E., Niermann, U., and Uysal, Z.: The Black Sea zooplankton: composition, spatial/temporal distribution and history of investigations, Turk. J. Zool., 23, 195-210, 1999.

Kovalev, A. V., Mazzocchi, M. G., Kideyş, A. E., Toklu, B., and Skryabin, V. A.: Seasonal Changes in the Composition and Abundance of Zooplankton in the Seas of the Mediterranean Basin, Turk. J. Zool., 27, 205-219, 2003.

Krumhardt, K. M., Lovenduski, N. S., Iglesias-Rodriguez, M. D., and Kleypas, J. A.: Coccolithophore growth and calcification in a changing ocean, Prog. Oceanogr., 159, 276-295, 2017.

Kubryakov, A. A. and Stanichny, S. V.: Mean Dynamic Topography of the Black Sea, computed from altimetry, drifter measurements and hydrology data, Ocean Sci., 7, 745-753, https://doi.org/10.5194/os-7-745-2011, 2011.

Kubryakov, A. A., Stanichny, S. V., Zatsepin, A. G., and Kremenetskiy, V. V.: Long-term variations of the Black Sea dynamics and their impact on the marine ecosystem, J. Marine Syst., 163, 8094, https://doi.org/10.1016/j.jmarsys.2016.06.006, 2016.

Kubryakov, A. A., Stanichny, S. V., and Zatsepin, A. G.: Interannual variability of Danube waters propagation in summer period of 1992-2015 and its influence on the Black Sea ecosystem, J. Marine Syst., 179, 10-30, https://doi.org/10.1016/j.jmarsys.2017.11.001, 2018.

Kubryakov, A. A., Aleskerovà, A. A., Goryachkin, Y. N., Stanichny, S. V., Latushkin, A. A., and Fedirko, A. V.: Propagation of the Azov Sea waters in the Black sea under impact of variable winds, geostrophic currents and exchange in the Kerch Strait, Prog. Oceanogr., 176, 102119, https://doi.org/10.1016/j.pocean.2019.05.011, 2019a.

Kubryakov, A. A., Mikaelyan, A. S., and Stanichny, S. V.: Summer and winter coccolithophore blooms in the Black Sea and their impact on production of dissolved organic matter from Bio-Argo data, J. Marine Syst., 199, 103220, https://doi.org/10.1016/j.jmarsys.2019.103220, 2019b.

Kubryakov, A. A., Zatsepin, A. G., and Stanichny, S. V.: Anomalous summer-autumn phytoplankton bloom in 2015 in the Black Sea caused by several strong wind events, J. Marine Syst., 194, 1124, https://doi.org/10.1016/j.jmarsys.2019.02.004, 2019c.

Kubryakov, A. A., Mikaelyan, A. S., Stanichny, S. V., and Kubryakova, E. A.: Seasonal stages of chlorophyll - a vertical distribution and its relation to the light conditions in the Black Sea from Bio-Argo measurements, J. Geophys. Res.-Oceans, 125, e2020JC016790, https://doi.org/10.1029/2020JC016790, 2020.

Kubryakova, E. A., Kubryakov, A. A., and Mikaelyan, A. S.: Winter coccolithophore blooms in the Black Sea: Interannual variability and driving factors, J. Marine Syst., 213, 103461, https://doi.org/10.1016/j.jmarsys.2020.103461, 2021.

Lin, I., Liu, W. T., Wu, C.-C., Wong, G. T. F., Hu, C., Chen, Z., Liang, W.-D., Yang, Y., and Liu, K.-K.: New evidence for enhanced ocean primary production triggered by tropical cyclone, Geophys. Res. Lett., 30, 1718, https://doi.org/10.1029/2003GL017141, 2003.
Lomas, M. W. and Glibert, P. M.: Interactions between $\mathrm{NH}_{4}^{+}$and $\mathrm{NO}_{3}^{-}$uptake and assimilation: Comparisons of diatoms and dinoflagellates at several growth temperatures, Mar. Biol., 133, 541-551, https://doi.org/10.1007/s002270050494, 1999.

Luo, H., Bracco, A., Cardona, Y., and McWilliams, J. C.: Submesoscale circulation in the northern Gulf of Mexico: Surface processes and the impact of the freshwater river input, Ocean Model., 101, 68-82, https://doi.org/10.1016/j.ocemod.2016.03.003, 2016.

Mahadevan, A.: The impact of submesoscale physics on primary productivity of plankton, Annu. Rev. Mar. Sci., 8, 161-184, https://doi.org/10.1146/annurev-marine-010814-015912, 2016.

Mihnea, P. E.: Major shifts in the phytoplankton community (19801994) in the Romanian Black Sea, Oceanol. Acta, 20, 119-129, 1997.

Mikaelyan, A. S., Pautova, L. A., Pogosyan, S. I., and Sukhanova, I. N.: Summer bloom of coccolithophorids in the northeastern Black Sea, Oceanology, 45, 127-138, 2005.

Mikaelyan, A. S., Silkin, V. A., and Pautova, L. A.: Coccolithophorids in the Black Sea: their interannual and long-term changes, Oceanology, 51, 39-48, https://doi.org/10.1134/S0001437011010127, 2011.

Mikaelyan, A. S., Pautova, L. A., Chasovnikov, V. K., Mosharov, S. A., and Silkin, V. A.: Alternation of diatoms and coccolithophores in the north-eastern Black Sea: a response to nutrient changes, Hydrobiologia, 755, 89-105, https://doi.org/10.1007/s10750-015-2219-z, 2015.

Mikaelyan, A. S., Shapiro, G. I., Chasovnikov, V. K., Wobus, F., and Zanacchi, M.: Drivers of the autumn phytoplankton development in the open Black Sea, J. Marine Syst., 174, 1-11, https://doi.org/10.1016/j.jmarsys.2017.05.006, 2017.

Mikaelyan, A. S., Kubryakov, A. A., Silkin, V. A., Pautova, L. A., and Chasovnikov, V. K.: Regional climate and patterns of phytoplankton annual succession in the open waters of the Black Sea, Deep-Sea Res. Pt. I, 142, 44-57, https://doi.org/10.1016/j.dsr.2018.08.001, 2018.

Mikaelyan, A. S., Mosharov, S. A., Kubryakov, A. A., Pautova, L. A., Fedorov, A., and Chasovnikov, V. K.: The impact of physical processes on taxonomic composition, distribution and growth of phytoplankton in the open Black Sea, J. Marine Syst., 208, 103368, https://doi.org/10.1016/j.jmarsys.2020.103368, 2020.

Miller, W. D., Harding Jr., L. W., and Adolf, J. E.: Hurricane Isabel generated an unusual fall bloom in Chesapeake Bay, Geophys. Res. Lett., 33, L06612, https://doi.org/10.1029/2005GL025658, 2006.

Moore, T. S., Dowell, M. D., and Franz, B. A.: Detection of coccolithophore blooms in ocean color satellite imagery: A generalized approach for use with multiple sensors, Remote Sens. Environ., 117, 249-263, https://doi.org/10.1016/j.rse.2011.10.001, 2012.

Morozov, E., Kondrik, D., Fedorova, A., Pozdnyakov, D., Tang, D. L., and Pettersson, L.: A spaceborne assessment of cyclone impacts on Barents Sea surface temperature and chlorophyll, Int. J. Remote Sens., 36, 1921-1941, https://doi.org/10.1080/01431161.2015.1029098, 2015.

NASA Goddard Space Flight Center: Moderate-resolution Imaging Spectroradiometer (MODIS) Aqua Ocean Color Data, NASA Goddard Space Flight Center, Ocean Ecology Laboratory, Ocean Biology Processing Group, 2018 
Reprocessing. NASA OB.DAAC, Greenbelt, MD, USA, https://doi.org/10.5067/AQUA/MODIS/L2/OC/2018, 2018.

Nejstgaard, J. C., Gismervik, I., and Solberg, P. T.: Feeding and reproduction by Calanus finmarchicus, and microzooplankton grazing during mesocosm blooms of diatoms and the coccolithophore Emiliania huxleyi, Mar. Ecol. Prog. Ser., 47, 197-217, https://doi.org/10.3354/meps147197, 1997.

Nezlin, N. P.: Seasonal and interannual variability of remotely sensed chlorophyll, in: The Black Sea Environment, edited by: Kostianoy, A. G. and Kosarev, A. N., Springer, Berlin, Heidelberg, Germany, 333-349, https://doi.org/10.1007/698_5_063, 2006.

Oguz, T., Macias, D., and Tintore, J.: Ageostrophic frontal processes controlling phytoplankton production in the CatalanoBalearic Sea (Western Mediterranean), PLoS One, 10, e0129045, https://doi.org/10.1371/journal.pone.0129045, 2015.

Olson, M. B. and Strom, S. L.: Phytoplankton growth, microzooplankton herbivory and community structure in the southeast Bering Sea: Insight into the formation and temporal persistence of an Emiliania huxleyi bloom, Deep-Sea Res. Pt. II, 49, 59695990, 2002.

Ostrovskii, A. G. and Zatsepin, A. G.: Intense ventilation of the Black Sea pycnocline due to vertical turbulent exchange in the Rim Current area, Deep-Sea Res. Pt. I, 116, 1-13, https://doi.org/10.1016/j.dsr.2016.07.011, 2016.

Özsoy, E. and Ünlüata, Ü.: Oceanography of the Black Sea: a review of some recent results, Earth-Sci. Rev., 42, 231-272, https://doi.org/10.1016/S0012-8252(97)81859-4, 1997.

Pautova, L. A., Mikaelyan, A. S., and Silkin, V. A.: Structure of plankton phytocoenoses in the shelf waters of the northeastern Black Sea during the Emiliania huxleyi bloom in 2002-2005, Oceanology, 47, 377-385, https://doi.org/10.1134/S0001437007030101, 2007.

Podymov, O., Zatsepin, A., Kubryakov, A., and Ostrovskii, A.: Seasonal and interannual variability of vertical turbulent exchange coefficient in the Black Sea pycnocline in 2013-2016 and its relation to variability of mean kinetic energy of surface currents, Ocean Dynam., 70, 199-211, https://doi.org/10.1007/s10236019-01331-w, 2020.

Poulton, A. J., Holligan, P. M., Charalampopoulou, A., and Adey, T. R.: Coccolithophore ecology in the tropical and subtropical Atlantic Ocean: New perspectives from the Atlantic meridional transect (AMT) program, Prog. Oceanogr., 158, 150-170, https://doi.org/10.1016/j.pocean.2017.01.003, 2017.

Pytharoulis, L., Craig, G. C., and Ballard, S. P.: Study of the hurricane-like Mediterranean cyclone of January 1995, Phys. Chem. Earth Pt. B, 24, 627-632, https://doi.org/10.1016/S14641909(99)00056-8, 1999.

Remote Sensing Department: Advanced Very-High-Resolution Radiometer (AVHRR) data, Remote Sensing Department, Marine Hydrophysical Institute, Russian Academy of Science, available at: http://dvs.net.ru/mp/data/200509bs_sst.shtml, last access: 11 May 2021.

Ricciardulli, L., Wentz, F. J., and Smith, D. K.: Remote Sensing Systems QuikSCAT Ku-2011, Orbital Swath Ocean Vector Winds L2B, Version 4, Remote Sensing Systems, Santa Rosa, CA, available at: http://www.remss.com/missions/qscat/ (last access: 9 May 2020), 2011.
Rigual Hernández, A. S., Flores, J. A., Sierro, F. J., Fuertes, M. A., Cros, L., and Trull, T. W.: Coccolithophore populations and their contribution to carbonate export during an annual cycle in the Australian sector of the Antarctic zone, Biogeosciences, 15, 1843-1862, https://doi.org/10.5194/bg-15-1843-2018, 2018.

Rigual Hernández, A. S., Trull, T. W., Nodder, S. D., Flores, J. A., Bostock, H., Abrantes, F., Eriksen, R. S., Sierro, F. J., Davies, D. M., Ballegeer, A.-M., Fuertes, M. A., and Northcote, L. C.: Coccolithophore biodiversity controls carbonate export in the Southern Ocean, Biogeosciences, 17, 245-263, https://doi.org/10.5194/bg-17-245-2020, 2020.

Rost, B. and Riebesell, U.: Coccolithophores and the biological pump: responses to environmental changes, in: Coccolithophores, edited by: Thierstein, H. R. and Young, J. R., Springer, Berlin, Heidelberg, Germany, https://doi.org/10.1007/978-3-662-06278-4_5, 2004.

Saliot, A., Derieux, S., Sadouni, N., Bouloubassi, I., Fillaux, J., Dagaut, J., Momzikoff, A., Gondry, G., Guillou, C., Breas, O., Cauwet, G., and Deliat, G.: Winter and spring characterization of particulate and dissolved organic matter in the DanubeBlack Sea mixing zone, Estuar. Coast. Shelf S., 54, 355-367, https://doi.org/10.1006/ecss.2000.0652, 2002.

Shi, W. and Wang, M.: Observations of a Hurricane Katrina-induced phytoplankton bloom in the Gulf of Mexico, Geophys. Res. Lett., 34, L11607, https://doi.org/10.1029/2007GL029724, 2007.

Shutler, J. D., Land, P. E., Brown, C. W., Findlay, H. S., Donlon, C. J., Medland, M., Snooke, R., and Blackford, J. C.: Coccolithophore surface distributions in the North Atlantic and their modulation of the air-sea flux of $\mathrm{CO}_{2}$ from 10 years of satellite Earth observation data, Biogeosciences, 10, 2699-2709, https://doi.org/10.5194/bg-10-2699-2013, 2013.

Silkin, V. A., Pautova, L. A., and Mikaelyan, A. S.: Role of phosphorus in the regulation of Emiliania huxleyi (Lohm.) Hay et Mohl. (Haptophyta) blooms in the northeastern Black Sea, International Journal on Algae, 11, 211-221, https://doi.org/10.1615/InterJAlgae.v11.i3.20, 2009.

Silkin, V. A., Pautova, L. A., Pakhomova, S. V., Lifanchuk, A. V., Yakushev, E. V., and Chasovnikov, V. K.: Environmental control on phytoplankton community structure in the NE Black Sea, J. Exp. Mar. Biol. Ecol., 461, 267-274, https://doi.org/10.1016/j.jembe.2014.08.009, 2014.

Silkin, V. A., Pautova, L. A., Giordano, M., Chasovnikov, V. K., Vostokov, S. V., Podymov, O. I., Pakhomova, S. V., and Moskalenko, L. V.: Drivers of phytoplankton blooms in the northeastern Black Sea, Mar. Pollut. Bull., 138, 274-284, https://doi.org/10.1016/j.marpolbul.2018.11.042, 2019.

Sorokin, Y. U. I. (Ed.): The Black Sea, in: ecosystem of the world, estuaries and enclosed seas, Elsevier, Amsterdam, The Netherlands, 1983.

Stelmakh, L. V.: Microzooplankton grazing impact on phytoplankton blooms in the coastal seawater of the southern Crimea (Black Sea), Int. J. Mar. Sci., 3, 121-127, https://doi.org/10.5376/ijms.2013.03.0015, 2013.

Stelmakh, L. V., Senicheva, M. I., and Babich, I. I.: Ecological and physiological bases of Emiliania huxleyi bloom in Sevastopol Bay, Ekologiya Morya, 77, 28-32, 2009 (in Russian).

Sukhanova, N.: Phenomenon of the mass development of coccolithophores during the late autumn period in the Black Sea, Dokl. Akad. Nauk+, 340, 256-259, 1995 (in Russian). 
Sur, H. İ., Özsoy, E., and Ünlüata, Ü.: Boundary current instabilities, upwelling, shelf mixing and eutrophication processes in the Black Sea, Prog. Oceanogr., 33, 249-302, https://doi.org/10.1016/0079-6611(94)90020-5, 1994.

Sur, H. İ., Ilyin, Y. P., Özsoy, E., and Ünlüata, Ü.: Coastal/deep ocean interactions in the Black Sea and their ecological/environmental impacts, J. Marine Syst., 7, 293-320, https://doi.org/10.1016/0924-7963(95)00030-5, 1996.

Tsuchiya, K., Kuwahara, V. S., Yoshiki, T., Nakajima, R., Miyaguchi, H., Kumekawa, N., Kikuchi, T., and Toda, T.: Phytoplankton community response and succession in relation to typhoon passages in the coastal waters of Japan, J. Plankton Res., 36, 424-438, https://doi.org/10.1093/plankt/fbt127, 2013.

Tuğrul, S., Murray, J. W., Friederich, G. E., and Salihoğlu, İ.: Spatial and temporal variability in the chemical properties of the oxic and suboxic layers of the Black Sea, J. Marine Syst., 135, 29-43, https://doi.org/10.1016/j.jmarsys.2013.09.008, 2014.

Türkoğlu, M.: Winter bloom of coccolithophore Emiliania huxleyi and environmental conditions in the Dardanelles, Hydrol. Res., 41, 104-114, https://doi.org/10.2166/nh.2010.124, 2010.

Tyrrell, T. and Merico, A.: Emiliania huxleyi: bloom observations and the conditions that induce them, in: Coccolithophores, edited by: Thierstein, H. R. and Young, J. R., Springer, Berlin, Heidelberg, Germany, 75-97, https://doi.org/10.1007/978-3-66206278-4_4, 2004.

Wu, Y., Platt, T., Tang, C. C., Sathyendranath, S., Devred, E., and $\mathrm{Gu}, \mathrm{S}$.: A summer phytoplankton bloom triggered by high wind events in the Labrador Sea, July 2006, Geophys. Res. Lett., 35, L10606, https://doi.org/10.1029/2008GL033561, 2008.

Yakushev, E. V., Pollehne, F., Jost, G., Kuznetsov, I., Schneider, B., and Umlauf, L.: Analysis of the water column oxic/anoxic interface in the Black and Baltic seas with a numerical model, Mar. Chem., 107, 388-410, https://doi.org/10.1016/j.marchem.2007.06.003, 2007.
Yankovsky, A. E., Lemeshko, E. M., and Ilyin, Y. P.: The influence of shelfbreak forcing on the alongshelf penetration of the Danube buoyant water, Black Sea, Cont. Shelf Res., 24, 10831098, https://doi.org/10.1016/j.csr.2004.03.007, 2004.

Yarovaya, D. A., Efimov, V. V., Shokurov, M. V., Stanichnyi, S. V., and Barabanov, V. S.: A quasitropical cyclone over the Black Sea: observations and numerical simulation, Physical Oceanography, 18, 154-167, https://doi.org/10.1007/s11110-008-9018-2, 2008.

Yasakova, O. N. and Stanichny, S. V.: Abnormal blooming by Emiliania huxleyi (Prymnesiophyceae) in the Black Sea in 2012, Morskyi Ekolohichnyi Zhurnal, 11, p. 54, 2012 (in Russian).

Yasakova, O. N., Okolodkov, Y. B., and Chasovnikov, V. K.: Increasing contribution of coccolithophorids to the phytoplankton in the northeastern Black Sea, Mar. Pollut. Bull., 124, 526-534, https://doi.org/10.1016/j.marpolbul.2017.07.037, 2017.

Zatsepin, A., Kubryakov, A., Aleskerovà, A. A., Elkin, D., and Kukleva, O.: Physical mechanisms of submesoscale eddies generation: evidences from laboratory modeling and satellite data in the Black Sea, Ocean Dynam., 69, 253-266, https://doi.org/10.1007/s10236-018-1239-4, 2019.

Zhu, M., Paerl, H. W., Zhu, G., Wu, T., Li, W., Shi, K., Zhao, L., Zhang, Yu., Qin, B., and Caruso, A. M.: The role of tropical cyclones in stimulating cyanobacterial (Microcystis spp.) blooms in hypertrophic Lake Taihu, China, Harmful Algae, 39, 310-321, https://doi.org/10.1016/j.hal.2014.09.003, 2014. 